
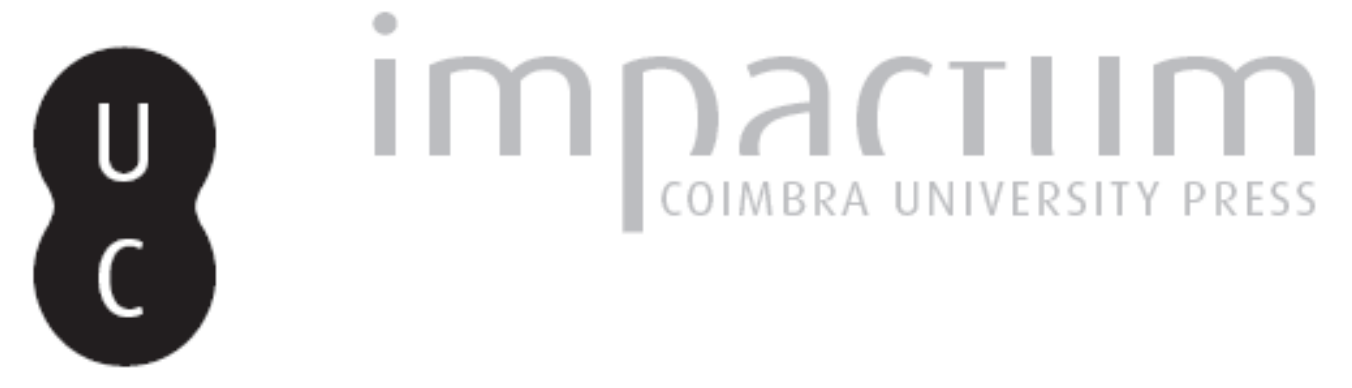

\title{
Laches before Charmides: fictive chronology and platonic pedagogy
}

Autor(es): $\quad$ Altman, William H. F.

Publicado por: Imprensa da Universidade de Coimbra

URL persistente:

URI:http://hdl.handle.net/10316.2/42193

DOI:

DOI:https://doi.org/10.14195/2183-4105_10_1

Accessed : $\quad$ 26-Apr-2023 14:50:17

A navegação consulta e descarregamento dos títulos inseridos nas Bibliotecas Digitais UC Digitalis, UC Pombalina e UC Impactum, pressupõem a aceitação plena e sem reservas dos Termos e Condições de Uso destas Bibliotecas Digitais, disponíveis em https://digitalis.uc.pt/pt-pt/termos.

Conforme exposto nos referidos Termos e Condições de Uso, o descarregamento de títulos de acesso restrito requer uma licença válida de autorização devendo o utilizador aceder ao(s) documento(s) a partir de um endereço de IP da instituição detentora da supramencionada licença.

Ao utilizador é apenas permitido o descarregamento para uso pessoal, pelo que o emprego do(s) título(s) descarregado(s) para outro fim, designadamente comercial, carece de autorização do respetivo autor ou editor da obra.

Na medida em que todas as obras da UC Digitalis se encontram protegidas pelo Código do Direito de Autor e Direitos Conexos e demais legislação aplicável, toda a cópia, parcial ou total, deste documento, nos casos em que é legalmente admitida, deverá conter ou fazer-se acompanhar por este aviso.

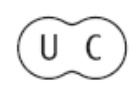



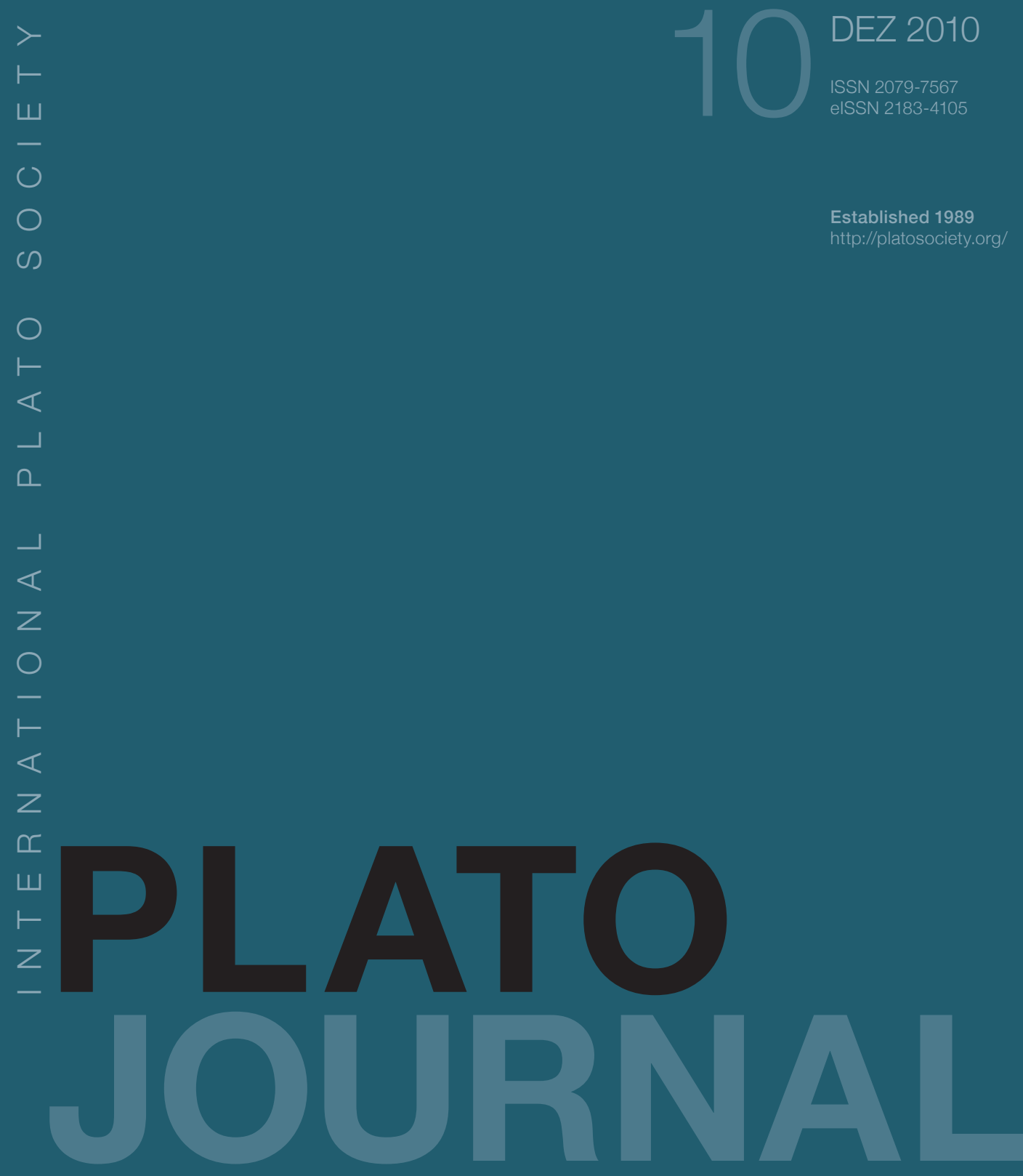

Société Platonicienne Internationale

Associazione Internazionale dei Platonisti

Sociedad Internacional

de Platonistas

Internationale

Platon-Gesellschaft 


\section{LACHES BEFORE CHARMIDES Fictive Chronology and Platonic PEDAGOGY}

Despite long overdue scholarly discontent with the nineteenth century dogma that his dialogues are best understood in terms of Plato's intellectual development, ${ }^{1}$ its most recent rival suffers from a similar disability. Christened "fictive chronology" by Charles Griswold Jr. in 1999,2 an ordering of the dialogues in relation to their dramatic dates replaces a story about Plato's with another about Socrates' development: both stories suffer from a characteristically modern and un-Platonic concern with time, change, and Becoming. The persistence of attempts to outflank Platonism by historicizing Plato is an interesting phenomenon in its own right: in addition to revealing the enduring influence of evolutionary patterns of thought, its latent cause with respect to Socrates is the influence of Leo Strauss, principal twentieth-century critic of the developmentalist reading of Plato and inventor of its Socratic counterpart. ${ }^{3}$ In any case, the research of Debra Nails ${ }^{4}$ has now allowed Catherine Zuckert ${ }^{5}$ to produce a comprehensive reading of all the Platonic dialogues based on fictive chronology while Laurence Lampert (2010) has recently applied the principle in detail to Protagoras, Charmides, and Republic.

Before this new form of chronological over-determination becomes a twenty-first century dogma, Laches and Charmides will here be used to illustrate both the inadequacy of ordering the dialogues by fictive chronology and the merits of replacing an admittedly out-dated developmentalist approach with a new

For Mrs. Appleyard's youngest daughter: Rosamond Kent Sprague. Except where noted, all translations from Lach. and Charm. are hers; citations of the text are based on Burnet 1900-07. Thanks are also due to Jonathan R. Bruno, Tom Brickhouse, Dimitri El Murr and an anonymous reader; the latter's suggestions and criticisms were very helpful.

1 Among many others, see Rowe 2007, 48-51, 248. Gould 1987 is a good example of a "developmentalist" reading of $L$ ach.

${ }^{2}$ Griswold 1999, 386-90 especially 387.

${ }^{3}$ Strauss 1966 and Strauss 1989, 103-183, especially 154: "The individual Platonic dialogue is not a chapter from the Encyclopaedia of the Philosophical Sciences or from a system of philosophy, nor is it the product of an occasion or the relic of a stage of Plato's development." Strauss's account of Socratic "development" is usefully summarized at Zuckert 1996, 132-64.

${ }^{4}$ Nails 2002, especially 307-30.

${ }^{5}$ See Zuckert 2009, 8-19, especially 9 n. 19.

PLATO, The electronic Journal of the International Plato Society, n 10, 2010. http://gramata.univ-paris1.fr/Plato/article95.html, (c) All rights of reproduction of any form reserved. 
conception of Platonic pedagogy based on a more natural conception of reading order. $^{6}$ The threshold form of my thesis is that Charmides must not be read in isolation from Laches on the basis of fictive chronology (Sections 1-3) while its more developed form (Sections 3-5) uses the reading order hypothesis to show that Laches actually precedes Charmides on pedagogical grounds despite fictive chronology.

\section{Section 1. Fictive Chronology and the Charmides}

Consistent with the moderation of her path-breaking book, ${ }^{7}$ Zuckert avoids the worst ramifications of considering Charmides and Laches in accordance with fictive chronology. Given the dates of Potidaea and Delium (Charm. 153al and Lach. 180b1-2), she naturally considers Charmides prior to Laches but despite a considerable chronological interval between the two dramatic settings, she nevertheless manages to preserve the traditional and indeed obvious juxtaposition of the two (cf. Nails 2002, 311-2) by discussing Laches immediately after Charmides (Zuckert 2009, 237-58). But this chronological juxtaposition is only made possible by her decision to ignore the possibility that any of the conversations depicted in Gorgias, ${ }^{8}$ the pair of Hippias dialogues, ${ }^{9}$ and the Republic, ${ }^{10}$ take place before Laches. It should be noted that Nails classified these four as "Dialogues with Problematic Dramatic Dates" (Nails 2002, 324-7); the presence of Plato's masterpiece among them should probably be taken as a reductio ad absurdum on the entire enterprise. ${ }^{11}$ But Zuckert's decision to preserve, within the context of fictive chronology, the Charmides/Laches

\footnotetext{
${ }^{6}$ See Altman 2010; the influence of e.g. Kahn 1996 qualifies the use of "new." For an early application of Kahn's "prolepsis" (Kahn 1996, 48 and Kahn 1981) to Charm., see Van Der Ben 1985, especially 95 and $98-9$ n. 14.

${ }^{7}$ Her independence from Strauss is particularly praiseworthy; see 224 n. 16, 299, 354 n. 136, 363 n. 153 , and 493 .

${ }^{8}$ Although the only attested visit of Gorgias to Athens was in 427 B.C. (i.e. between Potidaea and Delium) other indications suggest a later date or rather a hopeless muddle where fictive chronology is concerned; see Nails 2002, 326-7.

${ }^{9}$ These dialogues are considered at Zuckert 2009, 257-77, i.e. the fourth part of Chapter 4 . The conversations with Hippias refer to the visit of Gorgias to Athens (see previous note and Nails $2002,313$.

${ }^{10}$ Zuckert 2009, 301-2 n. 43; for similar passages, see 353 n. 134 and 487 n. 8.

${ }^{11}$ Nails 2002, 324: "The version of Republic that has come down to us is not a seamless dialogue, and it was not edited from the standpoint of dramatic date; thus there would be jarring anachronisms if any of the candidate specific dates between 432 and 404 were assigned definitively." To preserve the possibility that Plato was concerned with fictive chronology, Nails revives the fiction of an independent Thrasymachus (see Kahn 1993) and suggests that we are confined to an unedited version of Rep.
}

PLATO, The electronic Journal of the International Plato Society, n 10, 2010. http://gramata.univ-paris1.fr/Plato/article95.html, (c) All rights of reproduction of any form reserved. 
juxtaposition conceals to a large extent the most dangerous implications inherent in her organizing principle.

These implications become more obvious in Lampert's book: he scarcely mentions Laches while Charmides is preceded by Protagoras (and the Alcibiades dialogues $)^{12}$ and then followed by Republic, a dialogue for which he finds a specific date only a few weeks after Charmides (Lampert 2010, 405-11). By reading Republic as the sequel to Charmides, Lampert argues that the charms from Thrace to which Socrates refers in Charmides but never actually reveals there (cf. Charm. 156d3-5 and 175e3) are to be sought and found in Republic; ${ }^{13}$ this connection ultimately becomes the basis for divorcing Plato from the Idea of the Good and redefining the shorter, not the Longer Way (Rep. 504b1-505a4), in reference to it. ${ }^{14}$ The significant point here is that because he is only considering a small number of dialogues in an exclusively chronological context, Lampert has no reason to consider Charmides in relation to Laches. Quite apart from his understanding of the Charmides-Republic dyad, Lampert ignores far more obvious or natural connections, like those that caused Thrasyllus to place Cleitophon before Republic and Charmides next to Laches. Zuckert, by contrast, finds a way to preserve these Thrasyllan connections.

Zuckert's Chapter 4 ('Socrates Interrogates His Contemporaries about the Noble and Good") is divided into four parts, the first on Protagoras, the second divided between the two Alcibiades dialogues and Charmides (Zuckert 2009, 237 47), the third on Laches (Zuckert 2009, 247-58), and the fourth on the two Hippias dialogues. This structure emphasizes the links between Charmides and Alcibiades Major and there are many such links, not all of them mentioned by Zuckert. ${ }^{15}$ Her guiding statement builds on the presence of both Critias and Alcibiades in Protagoras (Prot. 316a4-5) and, more importantly, on the juxtaposition in Xenophon's Memorabilia 1.2.12-48 of two men "Socrates was

\footnotetext{
${ }^{12}$ In arguing for the dramatic priority of Prot. to Alcibiades Major, both Zuckert and Lampert (Lampert 2010, 126 n. 146 and 143-4; Zuckert 2009, 217-8 n. 4), correctly draw attention to the fact that Socrates does not actually speak with Alcibiades in the former. But both miss what I regard as the most important "natural" indication of sequence: at Alcibiades Major 111a1-4, the otherwise astonishingly obtuse youth (cf. 108c6-d4) employs an ingenious argument Protagoras had used in his hearing at Prot.327e3-328a1; see Denyer 2001, 122. For the pedagogical value or purpose of Prot., see Guthrie 1975, 235.

${ }^{13}$ Lampert 2010, 233, 241, 245, 249, 271, 305-6, and 388.

${ }^{14}$ Lampert 2010, 296 and 353: "The short road leads to the bright and beautiful that secures the moral universe in the ruling principle of the Good."

${ }^{15}$ The most obvious example is the definition of temperance as self-knowledge; see Denyer 2001, 222. Cf. Lampert 2010, 156-7 and 180 n. 60.
}

PLATO, The electronic Journal of the International Plato Society, n 10, 2010. http://gramata.univ-paris1.fr/Plato/article95.html, (c) All rights of reproduction of any form reserved. 
not able to divert from their tyrannous ambitions." 16 But her principal concern is the following: "In the Alcibiades I and the Charmides, Socrates shows that acquiring knowledge is necessarily an interactive process." ${ }^{17}$ This is clearly a significant link although she weakens her case for the juxtaposition of Charmides and Alcibiades Major by astutely pointing out a significant difference between the two: the former is a private conversation while Critias in Charmides (like Nicias in Laches) must be concerned with his audience's reaction (Zuckert 2009, 245-6).

When Zuckert turns to Laches, however, she for the most part fails to draw attention to the many connections between it and Charmides that will be discussed in Section 3.18 The only time she mentions Charmides in her account of Laches is both disjunctive and dependent on the presuppositions of fictive chronology:

By showing that Socrates was no longer known only to the young men and foreign teachers who frequented the gymnasia but was now recognized by the leading conservative politicians in Athens (Nicias and Laches), if for different reasons, Plato indicates that the philosopher's reputation had grown in the ten years between this conversation and that depicted in Charmides. Nicias, for example, knows of Socrates.

(Zuckert 2009, 248)

Given that Critias and young Charmides (cf. Charm. 156a6-7 and Lach. 181a13) are no less familiar than Nicias is with the reputation of Socrates as well as his views or statements (cf. Charm. 161b5-6 and Lach. 194d1-2), and that both dialogues take place in gymnasia (cf. Lach. 178a1 and Euthyd. 271d3), ${ }^{19}$ this distinction seems forced. And even though Zuckert draws attention to the important and obvious connection between Laches and Protagoras on the

${ }_{16}$ Zuckert 2009, 229 and (on Xenophon) n. 24; cf. Lampert 2010, 134-40. Zuckert offers no defense for using Xenophon to elucidate Plato's arrangement of the dialogues but she presupposes-accurately, in my judgment-Plato's knowledge of Xenophon.

${ }^{17}$ Zuckert 2009, 247; cf. 235, 243, and 246.

${ }^{18}$ Zuckert 2009, 256 n. 72 notes without comment that Socrates quotes the same passage from Homer in both dialogues.

${ }^{19}$ Emlyn-Jones 1996, 2: "The precise venue of the conversation is not stated; the exhibition of hoplomachia the participants have just been watching (178a1) may be presumed to have taken place in one of the Athenian Gymnasia, the dramatic setting for many of Plato's Dialogues and where Socrates often converses (see e.g. Lys. 204a)." Both Lys. and Euthyd. take place at the Lyceum, the only identified venue for a display of martial arts in Plato (Euthyd. 271a1). And Stesilaus (Lach. 183c8-184a7) must be reckoned a foreign teacher (cf. the passage from Zuckert quoted above).

PLATO, The electronic Journal of the International Plato Society, n 10, 2010. http://gramata.univ-paris1.fr/Plato/article95.html, (c) All rights of reproduction of any form reserved. 
meaning of courage, ${ }^{20}$ she fails to note the significant connections between Laches and Alcibiades that will be discussion in Section 2. In conclusion, her emphasis on fictive chronology leads her to neglect the close connections between Laches and Charmides and even tempts her to suggest a thematic disjunction between the two.

\section{Section 2. Laches and Alcibiades Major}

In order to address the question of whether young men (Lach. 185c3) ought to learn how to fight in armor, Socrates secures prior agreement from Nicias that if we are consulting about eye-medicine, we are really discussing the eye ( $\mathrm{Lach}$. 185c5-9), if bridles, the horse (Lach. 185d1-5), and generally, the thing for the sake of which we are consulting rather than the thing that will be applied to it (Lach. 185d5-12). Since a plausible case could be made for the view that training in martial arts is an important part of physical education, it is significant that Socrates refuses to identify the body as the thing for the sake of which we are discussing fighting in armor:

Socrates. So do we now declare that we are considering a form of study for the sake of the souls of young men.

(Lach. 185e1-2)

In his commentary on this passage, Chris Emlyn-Jones (1996, 77) remarks:

S. [sc. Socrates] makes this basic move very casually, and receives immediate and unquestioning assent from N. [sc. Nicias], which suggests that Plato does not believe that $S$. is introducing a controversial or difficult idea.

It would be more accurate and natural to say-and with this suggestion I broach the question of a Platonic pedagogy based on reading order-that Plato presupposes his reader's familiarity with Alcibiades Major. It is here that Socrates asks Alcibiades a series of questions leading the young man to assert (cf. Alcibiades Major 112d10-113b7) that he himself is not his body but his soul. ${ }^{21}$ And this is

\footnotetext{
${ }^{20}$ Zuckert 2009, 252-3; in addition to Denyer 2008, 174-5, see Erbse 1968 and Devereux 1992.

${ }^{21}$ See Denyer 2001, 213-20 on Alcibiades Major 129b5-130e6.
}

PLATO, The electronic Journal of the International Plato Society, n 10, 2010. http://gramata.univ-paris1.fr/Plato/article95.html, (c) All rights of reproduction of any form reserved. 
only one of three allusions between Laches $185 \mathrm{~d} 1$ and $190 \mathrm{~b} 1$ to this most accessible of Platonic dialogues. ${ }^{22}$

Socrates will prove that Alcibiades needs to attend to his soul by refuting the claim that the young man already knows what justice is. This refutation depends on the following seemingly innocuous exchange:

Socrates. And you know only the things you have learnt from others or discovered yourself? Alcibiades. What could I know besides?

(Alcibiades Major 106d4-6; translation W.R.M. Lamb)

While it is comparatively easy to reveal through questioning that Alcibiades has had no reliable teacher of justice (Alcibiades Major 111a5-112d9), Socrates must first extract an agreement from the young man that there never was a time at which he did not believe that he already knew what justice was (and therefore had an incentive to discover what it was for himself) before gaining agreement that the youth has not in fact discovered it for himself. ${ }^{23}$ In Laches, by contrast, Socrates requires no cross-examination to reveal his own status:

Now I, Lysimachus and Melesias, am the first to say, concerning myself, that I have had no teacher in the subject. And yet I longed after it from my youth up. But I did not have any money to give the sophists, who were the only ones who professed to be able to make a cultivated man out of me, and I myself, on the other hand, am unable to discover the art even now. ${ }^{24}$

${ }^{22}$ It goes without saying both that the authenticity of Alcibiades has been disputed and that Denyer 2001 will be reckoned an important milestone in its rehabilitation should it be once again embraced; see his nuanced discussion at Denyer 2001, 14-26. Its authenticity is defended at Zuckert 2009, 216 n. 2 and assumed in Lampert 2010. My own approach to restoring it to the canon would be based on pedagogical grounds as mediated by the concept of Reading Order. Note that although Alcibiades Major was often placed first in ancient reconstructions of Reading Order (see Denyer 2001, 14 n. 6), this placement was based on its content rather than its pedagogical accessibility to neophytes.

${ }^{23}$ See Denyer 2001, 101 for a list of much more compressed parallels (or references) to this passage in other dialogues; the connection between Lach. and Euthyd. will be discussed in Section 4. below.

${ }^{24}$ Lach. 186b8-c5. The art in question is that of caring for the souls of the youth (Lach. 186a8; cf. Alcibiades Major 130b2-11) so that they become good (Lach. 186b4-6; cf. Euthyd. 291d1-6). Although the possibility of irony in the quoted passage should not be ignored, Socrates has already given himself another way out before this confession (Lach. 186b1-5): "Or if any one of us says that he himself has had no teacher but has works of his own to tell of, then he ought to show which of the Athenians or foreigners, whether slave or free, is recognized to have become good by his influence." This escape route will be discussed in Section 4. with reference to Euthyd.

PLATO, The electronic Journal of the International Plato Society, n 10, 2010.

http://gramata.univ-paris1.fr/Plato/article95.html,

(c) All rights of reproduction of any form reserved. 
And it is the reader's familiarity with Alcibiades Major-where it is on the rich young man's past, not his future, ${ }^{25}$ that the Socratic refutation of self-discovery entirely depends-that unlocks the humor of what Socrates says next:

If Nicias or Laches had discovered it or learned it, I would not be surprised, because they are richer than I and so may have learned it from others, and also older, so they may have discovered it already.

(Lach. 186c5-8)

The third allusion connects the most beautiful passage in Alcibiades Major to the most confusing passage in Laches, a passage that will be considered in Section 5 below. In Alcibiades Major, Socrates uses the parallel between the eye and the soul to explain the acquisition of self-knowledge through interaction with another. ${ }^{26}$ In Laches, Socrates explicates an admittedly confusing general statement of methodology (Lach. 189e3-8) with the same analogy between the eye and sight (Lach. 190a1-b2) that he had applied in Alcibiades Major to the soul and the virtue of the soul, i.e. wisdom (Alcibiades Major 133b2-11), and that he now intends to apply first to the soul and virtue generally (Lach. 190b3-c7) and next to the soul and courage specifically (Lach. 190c8-e3). The fact that the identification of human beings with their souls in Laches actually begins with a reference to the eyes (Lach. 185c6; cf. Charm. 156b6) is but one further indication that the entire passage between $185 \mathrm{c} 5$ and 190e3 presupposes and is intended to remind the reader of Alcibiades Major. Naturally this kind of claim applies no less to Charmides: in addition to the fact that it revisits the theme of self-knowledge generally, the view of Socrates quoted by Critias (Charm. 161b6) leads eventually to a verbal identity with Alcibiades Major (Charm. $164 \mathrm{~d} 4$ and Alcibiades Major 131b4; cf. Denyer 2001, 222). But it is not because Charmides is set at approximately the same time period as Alcibiades Major that it echoes the earlier and simpler dialogue: both Charmides and Laches echo Alcibiades Major because they, despite the time-interval between Potidaea and Delium, are best understood as twins. ${ }^{27}$

${ }^{25}$ At Alcibiades Major 109e7, Socrates asserts that Alcibiades could have discovered for himself how to know about the just and unjust things (109e1-2) "if you thought you did not know" (Lamb). Although Laches is brought to a discontented confession of inability (Lach. 195a6-b4), Nicias places his ultimate confidence in being taught by others (Lach. 200b2-7).

${ }^{26}$ See Alcibiades Major 132c9-133c17 and Denyer 2001, 229-37; cf. Zuckert 2009, 235-47.

${ }^{27}$ Lost in the ancient debate about trilogies or tetralogies in Plato is the far more obvious and natural category of twin-dialogues (Zwillingsdialoge) of which Sophist and Statesman are the least controversial examples. In addition to the pair of Alcibiades and Hippias dialogues, one might also cite Timaeus/Critias, Hipparchus/Minos, and Laws/Epinomis. Since the authenticity debate has rendered this pattern all but invisible, a renewed recognition of the pattern necessarily adds a new dimension to the authenticity debate.

PLATO, The electronic Journal of the International Plato Society, n 10, 2010. http://gramata.univ-paris1.fr/Plato/article95.html, (c) All rights of reproduction of any form reserved. 


\section{Section 3. Charmides and Laches}

Here it is tempting to employ the least philosophical of proofs: the argumentum ad verecundiam. German scholars in particular have been drawing attention to the parallels between Charmides and Laches for the last hundred years. ${ }^{28}$ The most detailed and sensitive treatment of these parallels is Reinhard Dieterle's Platons Laches und Charmides; Untersuchungen zur elenktisch-aporetischen Struktur der platonischen Frübdialoge (1966). ${ }^{29}$ This claim is by no means intended to discount the contributions of my own countrymen in this field. In addition to Rosamond Kent Sprague (1973), the studies of Gerasimos Santas (1971 and 1973), Francisco J. Gonzalez (1995 and 1998), and Walter T. Schmid ${ }^{30}$ bear witness to the intimate connection between Charmides and Laches. ${ }^{31}$ Nor is ancient testimony lacking: Thrasyllus places the two side by side in his Fifth Tetralogy.

Without rejecting the many subtle and important parallels between Charmides and Laches identified by these and other scholars, my own approach to linking the two dialogues is intentionally superficial: how does Plato make it obvious to any given reader that the two are to be read and considered as a pair? The purpose of this paper is to use these particular twins in order to reject a proposal for reading the dialogues solely on the basis of fictive chronology, a proposal that threatens to disconnect them. The word "solely" is emphasized here because there is no question that in the case of e.g. Theaetetus, Euthyphro, Sophist, and Statesman, Plato has often made the chronological ordering of his dialogues obvious. Laches and Charmides are important in this context because even though they are separated in time as indicated by the dates of two important battles, they are nevertheless linked in many other obvious ways indicating that it was Plato's intention to have his readers read them together and, moreover, that it is this intention that best explains why so many have done so. To that extent, my purpose in exploring the link between Charmides and Laches is not only to call into question an exclusive reliance on fictive chronology as the basis for ordering Plato's dialogues but also to reject en passant two far more serious errors: the view

\footnotetext{
${ }^{28}$ Mutschmann 1911, 474 ("fast wie Zwillinge"); Gomperz 1912, 250; Pohlenz 1913, 56; and Natorp 1914, 20 (“Zwillingsbrüder”).

${ }^{29}$ See Dieterle 1966, 72-4, 142 n. 1 (see previous note), 162 n. 1, 163-4, 168 n. 3, 175-6, 183 n. 1 , 186 n. 3, 195 n. 1, 200 n. 3, 204 n. 1, 206 n. 1, 209 n. 1, 212 n. 2, 222, 228 n. 1, 231, 285, 295-6, 300 n. 1, 307 n. 1, and 308-19.

${ }^{30}$ Charm. is "sister dialogue" to Lach. at Schmid 1992, 1, 25, and 70; cf. Schmid 1998, 148 and 178 n. 22.

${ }^{31}$ Other instances could be found between Grote 1867, 468-501and Wolfsdorf 2005, 335-40.
} 
that Plato had no authorial intentions whatsoever and that each of his dialogues must be interpreted in complete isolation from all the rest (Press 1993).

The most obvious connection between Laches and Charmides is that each is concerned with a single virtue: this accounts for the ancient decision of Thrasyllus to link them with Theages and the modern decision to consider them most often in connection with Euthyphro (e.g. Crombie 1962). The facts that stand at the basis of disjoining the two on the basis of fictive chronology - the dates of Delium and Potidaea-offer another obvious link: two dialogues linked by concern with one particular virtue also emphasize Socrates' service as a soldier in one particular battle. ${ }^{32}$ Both dialogues likewise presuppose the reader's knowledge of history: certainly the dates of Potidaea and Delium depend on Thucydides. Of course the connection with history is probably far deeper: if Laches cannot be understood without Thucydides (who narrates the end of Nicias) the historical significance of Charmides depends on having read the account of Critias in Xenophon's Hellenica.

Closer to the text, particularly in the context of history, is Plato's decision not to name the dialogues Nicias and Critias; every competent teacher who considered the two dialogues as a pair would ask students to explain the analogy between the two titles and thus about Plato's intentions in having named them as he did. Another unmistakable link is the fact that Socrates quotes Odyssey 17.347 in both. Socrates quotes it at the end of Laches (Lach. 201b2-3) in order to encourage his interlocutors to pursue their inquiries into courage regardless of any considerations of shame, while he quotes it early in Charmides (Charm. 161a4) as a dubious argumentum ad verecundiam against Charmides' final attempt to discover for himself what temperance is before shamelessly passing off a statement that depends on the authority of Critias as his own (cf. Schmid 1992, 208-8 n. 4 and Hyland 1981, 69). The comparative complexity of these two identical citations - the subtle difference made palpable through the superficial similarity-corroborates R.K. Sprague's admirable comment: "I have placed Laches first as being simpler than the Charmides and as providing a more leisurely introduction to the Socratic method." ${ }^{33}$ When all is said and done, the most natural and therefore compelling reason for reading Laches before Charmides is that it proves to be easier to read and therefore consistent with a sound pedagogical practice evidently recognized as such by of one of history's greatest teachers. $^{34}$

\footnotetext{
${ }^{32}$ Both Symp. 221a2-b1 and Apol. 28e2-3 mention both battles.

${ }^{33}$ Sprague 1973, vii.

${ }^{34}$ Cf. Crombie 1962, 214: "The turn of courage comes in the Laches, and it is treated more intelligibly than self-restraint in the Charmides." An easily overlooked aspect of the increased difficulty of Charm. is that it deals with worse men than Lach.; cf. Rep. 409a1-e1.
} 


\section{Section 4. Between Euthydemus and Charmides}

As a great teacher, Plato was also playful (Rep. 536e3-537a1) and this fact becomes obvious to the student who begins to think in terms of reading order. There are, of course, obvious sequential connections between dialogues as is the case with Sophist and Statesman; other examples are the references to Parmenides at Sophist 217c4-7 and the allusions to Republic at Parmenides (Parm. 126a2; cf. Miller 1986, 15, 18, and 194 n. 13). But these hints indicate general priority rather than actual sequence. A better example of what I am calling a "natural" connection joins the end of Symposium, where Socrates departs for the Lyceum, to the beginning of Lysis, which discovers him en route thither (see Altman 2010). And the journey that begins at Agathon's house continues: Euthydemus is the only Platonic dialogue set in the Lyceum. This obvious and natural connection is decisive and having recognized it, the reader will easily discover additional reasons to think it deliberate on Plato's part. To begin with, Laches' entire posture, his self-confessed albeit only partial misology (Lach. 188c4-d2), offers pleasing counterpoint and a perfectly understandable response to the specious and repelling arguments the reader, not Laches, has just encountered in Euthydemus.

The more complex thematic advance Laches makes over Alcibiades also links Laches to Euthydemus. In Laches, Socrates offers a third way to prove that one knows what any given virtue is: in addition to being able to identify the teacher who has taught you, one may demonstrate its acquisition not simply by a spoken claim to self-discovery but through the deeds so highly valued by Laches (Lach. $188 \mathrm{~d} 2-8$; cf. Rep. 399a5-c4), i.e. by pointing out another person, whether free or slave, who has become good as a result of you (Lach. 186b1-5). As soon as Ctessippus-introduced to the reader in Lysis (Lysis 203a4) - is identified as playing Iolaus to Socrates' Hercules in his battle with Euthydemus the Hydra and Dionysiodorus the pesky crab (see Altman 2007, 371-5), Euthydemus becomes an illustration of Socrates' mastery of this virtuous pedagogy. By learning from Socrates how to turn the tricks of the brothers against themselves for the benefit of his beloved, Ctesippus the student proves his teacher "wrong"-or rather vindicates Socrates' provocative pedagogical practice-by doing more good than harm (Euthyd. 297d1-2). In the context of Euthydemus, then, Socrates' merely implicit profession of pedagogical ineptitude in Laches (Lach. 186c5) can hardly be considered definitive, especially since the dialogue ends with his commitment - within the limits of piety (Lach. 201c4-5; cf. Theages 130e5-7) to participate in the education of Thucydides and Aristides (Lach. 200b3-5; cf. Theages 130a4-e4).

PLATO, The electronic Journal of the International Plato Society, n 10, 2010. http://gramata.univ-paris1.fr/Plato/article95.html, (c) All rights of reproduction of any form reserved. 
It is, however, to far more obvious and natural connections that I am attempting to draw attention here. A subtle but unmistakable linguistic connection between Euthydemus and Laches-reminiscent of the twin citations of Homer's Odyssey that connect Laches with Charmides-occurs when Socrates offers himself "as a Carian" (cf. Lach. 187b1 and Euthyd. 285c1) while Crito's concern for Critobulus at the end of Euthydemus (306d2-307c4) is echoed by the concern of Melesius and Lysimachus for their sons at the beginning of Laches. But the natural connection-the one that makes Plato's intentions manifest to any reader-is the presence of martial arts in both dialogues: in addition to teaching a warlike eristic, Euthydemus and Dionysiodorus are also expert in fighting in armor (Euthyd. 271d4-272a1) while Laches opens immediately after a similar display. Having attended to natural connections obvious to any youngster, the careful reader (Rep. 537a1-2) will then be rewarded by a far deeper level of comprehension and to that deeper level it is now time to turn.

Charles H. Kahn concludes his chapter on Charmides with a discussion of Euthydemus (Kahn 1996, 206-9; cf. Kahn 1988, 548-9). But it is characteristic of Kahn's revolutionary notion of "proleptic" or "ingressive composition" (Kahn 1996, 59-60) that he gives the last word to Plato's masterpiece (Kahn 1996, 209): "Here as often we see that, in the threshold dialogues, all roads lead to the Republic." Kahn is pointing to the fact that the Idea of the Good offers Plato's solution to the infinite regress into which "the royal art" - itself analogous to "the knowledge of knowledge proposed in the Charmides"- stumbles in Euthydemus:

What began in the Laches and Charmides and continued in the Meno and Euthydemus as a search for beneficial knowledge, knowledge of the correct use of instrumental goods, finds its climax here at the end of Republic VI, in an appeal to knowledge of the good itself. ${ }^{35}$

Despite the fact that he places Euthydemus after Charmides instead of before Laches, ${ }^{36}$ Kahn's Plato and the Socratic Dialogue: The Philosophical Use of a Literary Form (1996) is the principal modern forerunner of the conception of Platonic pedagogy based on reading order for which I am arguing here: ${ }^{37}$ all of the dialogues Plato intends the student to read before Republic-including

\footnotetext{
${ }^{35}$ Kahn 1996, 209; cf. Rowe 2007, 248.

${ }^{36}$ In Kahn 1996, Lach. and Men. are treated in Chapter 6, Charm. in Chapter 7, and Euthyd. in Chapter 10 (321-5); he plays down the parallels between Lach. and Charm. at 183.

${ }^{37}$ Cf. Kahn 1996, 48: "My six stages may be thought of as the proposal for an ideal reading order." 
Euthydemus, Laches, Charmides, and Gorgias - are "proleptic" with respect to it. ${ }^{38}$ Once Charmides is recognized as closer to Republic VI than Euthydemus, it is easy to see why Laches stands between them notwithstanding the priorities of "fictive chronology."

Despite the fact that she is attacking Kahn where I find significant common ground with him, Mary Margaret McCabe makes precisely the right point about Eutbydemus in contrast to Republic:

The Euthydemus, on the other hand, claims that wisdom is an intrinsic good, good itself by itself. This seems to mean both that wisdom is itself a good and that it is the source of the goodness of any other goods there might be. But that thought, it might be said, is the complete opposite of the view offered in the Republic. For there the intrinsic good, though an object of knowledge, is the source of goodness independently of whether it is known.

(McCabe 2002, 4)

McCabe is right: "the royal art" in Euthydemus is not knowledge of the Good but is, itself, qua beneficial knowledge, good. ${ }^{39}$ Because it is assumed to be beneficial and thus makes men happy, this knowledge alone cannot be productive of things that are neither good nor bad..$^{40}$ In fact, once Ctesippus is recognized as Iolaus, "the royal art" is best understood as the pedagogical art of Socrates being

\footnotetext{
${ }^{38}$ Erbse 1968, 39 (translation mine): "What one would like to say about all the works of this period-at least about the dialogues between Protagoras and Republic-applies as well to Charmides: they are not only written in order to communicate isolated philosophical discoveries but are also at the same time a curriculum constructed from psychagogic points of view [ein nach psychagogischen Gesichtspunkten aufgebauter Lehrgang] that pursues the goal of preparing the reader for apprehending the Ideas."

${ }^{39}$ Euthyd. 292a4-b3 (translation W.H.D. Rouse): "Socrates: Then what of the art of kings, ruling all which it rules? What does it make? Perhaps you cannot say exactly. Crito: No indeed, I cannot. Socrates: Nor could we, my dear Crito. But I know one thing [ $\dot{\alpha} \lambda \lambda \dot{\alpha} \tau \circ \sigma \dot{\delta} \nu \delta \varepsilon \gamma \varepsilon$ oī $\sigma \alpha \alpha$, that if it is

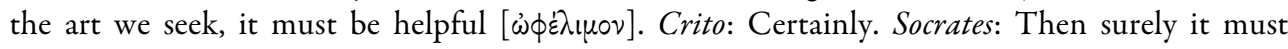
provide something good $\left[\dot{\alpha} \gamma \alpha \theta_{\dot{o} \nu} \gamma^{\dot{\varepsilon}} \tau \iota\right]$ for us? Crito: Obviously, Socrates. Socrates: But good

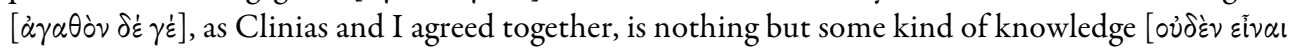
$\ddot{\alpha} \lambda \lambda \circ \ddot{\eta} \dot{\varepsilon} \pi \iota \tau \dot{\eta} \mu \eta \nu \tau \iota \nu \dot{\alpha}]$. Crito: Yes, you said so."

${ }^{40}$ Euthyd. 292b4-c2 (Rouse): "Socrates: Again, all the other 'works of politics' as one might call them-and there are many, for example, to make the people rich and free and without party

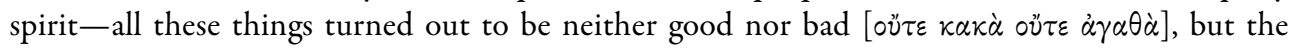

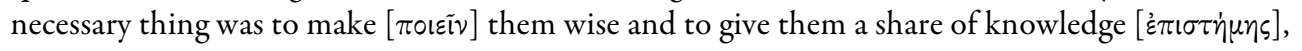
since knowledge was to be that which profited them $[\dot{\eta} \dot{\omega} \phi \varepsilon \lambda \circ \tilde{v} \sigma \dot{\alpha}]$ and made them happy

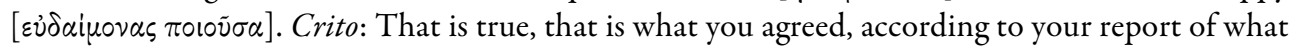

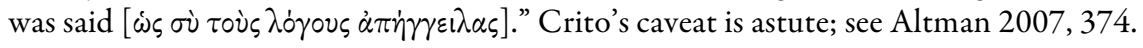

PLATO, The electronic Journal of the International Plato Society, n 10, 2010. http://gramata.univ-paris1.fr/Plato/article95.html, (c) All rights of reproduction of any form reserved. 
practiced in the dialogue. ${ }^{41}$ But even for the reader who fails to make this identification-i.e. the reader who, like Crito (Euthyd. 291a1), fails to recognize what sort of man Ctesippus is (Euthyd. 273a8) or has become (Altman 2007, 374) - the knowledge that can "impart no knowledge but itself alone," appears to be devoid of any other recognizable content. ${ }^{42}$ By sharply contrasting Euthydemus with Republic, McCabe goes on to reject Kahn's proleptic reading of the former:

In response, I maintain that the difference between an ethical theory where the explanation of value is located in a state of the agent and one where it is located outside is too radical for that story to be told. That is to say, between the two accounts of the good itself by itself in the Euthydemus and the Republic, the one where the good is internal to the agent, the other where it is external, there lies a genuine inconsistency, and one which is central to whatever view we might suppose that grand plan to be. Such a case, as I suggested, is hostile to the proleptic view.

(McCabe 2002, 5)

Because $\mathrm{Kahn}^{43}$ places Euthydemus closer to Republic than Charmides (and also fails to recognize the sharp distinction McCabe has correctly identified between Republic and Euthydemus), he also fails to see the equally sharp difference

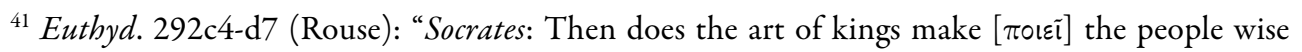

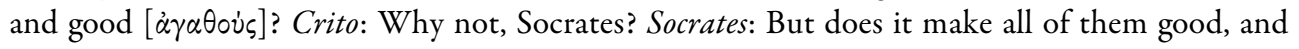
good in all respects? Does it impart every knowledge, shoemaking and carpentry and all the others? Crito: I do not think so, Socrates. Socrates: But what knowledge does it teach? [ $\dot{\alpha} \lambda \lambda \dot{\alpha} \tau i v \alpha$

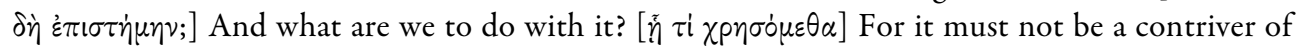
any of the products which are neither good nor bad [ $\tau \tilde{\omega} \nu \mu \dot{\eta} \tau \varepsilon \kappa \alpha \kappa \tilde{\omega} \nu \mu \dot{\eta} \tau \varepsilon \dot{\alpha} \gamma \alpha \theta \tilde{\omega} \nu]$; it must impart

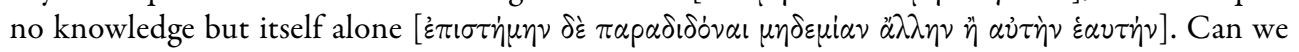
say what it is [ $\left.\tau i i_{\varsigma} \pi \circ \tau \dot{\varepsilon} \dot{\varepsilon} \sigma \tau \tau\right]$ ], and what we are to do with it? Would you like us to say it is the one

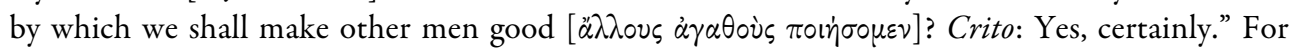

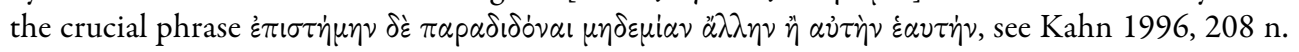
29.

${ }^{42}$ Euthyd.292d8-e7 (Rouse): "Socrates: And what shall these be good [à $\left.\gamma \alpha \theta_{0 i}\right]$ for, and how useful to us? Shall we say, to make others the same, and they to make others, and so on? And good at what? We cannot see, since we have despised [ $\dot{\eta} \tau \mu \dot{\alpha} \sigma \alpha \mu \varepsilon \nu]$ what are generally said to be the works of statecraft, and as the proverb goes, it is always 'Corinthus, son of Zeus.' We are just as far from

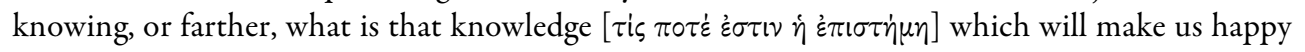

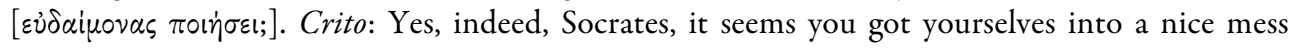

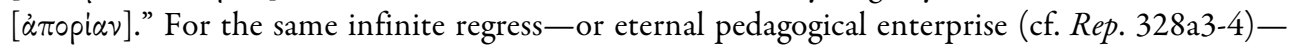

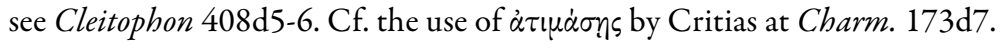

${ }^{43}$ Cf. Friedländer 1964, 77: "Behind this involved discussion [sc. in Charm.] which, in part, deliberately veils what is half revealed, there emerge a kind of knowledge that is superior to all other branches of knowledge and a conception of politics that is superior to the best practical brand because both aim at the highest good. This view may be confirmed by following this line of thought from the Laches and Charmides through Euthydemus up to the Republic."

PLATO, The electronic Journal of the International Plato Society, n 10, 2010. http://gramata.univ-paris1.fr/Plato/article95.html, (c) All rights of reproduction of any form reserved. 
between Euthydemus and Charmides. ${ }^{44}$ Before showing the place of Laches in Plato's pedagogical project and how it mediates "the difference" McCabe claims is "too radical" for any "story" based on "the proleptic view" to bridge, the first point to be made is that the only way Critias can avoid the conclusion that his version of temperance has no object except itself is to admit that it must know what is good and bad. ${ }^{45}$ In the Euthydemus, "the royal art" was presumed to be good qua knowledge (Euthyd. 292b1-2); the problem was to distinguish it from other kinds of knowledge whose products are no more good than bad ( $\tau \tilde{\omega} \nu \mu \dot{\eta} \tau \varepsilon$

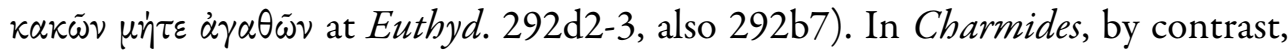
we are searching for a virtue, i.e. for something that we must assume from the start is beneficial, good, and fine (Wolfsdorf 2003, 291), and Critias is trying to show that it is a form of knowledge. The problem is that the only form of knowledge that Critias can show to be beneficial is not temperance. ${ }^{46}$ Intent on vindicating his definition of temperance at all costs, it is ironically the intemperate Critias to whom Plato entrusts the honor of introducing the proleptic phrase "the science of the Good;" ${ }^{77}$ given the tyrant's bent, it is perfectly appropriate that he relegates this majestic conception to a merely subordinate role:

\begin{abstract}
"But why should not this be beneficial $[\dot{\omega} \phi \varepsilon \lambda \circ \tilde{]}]$ ?" he said. "Because if temperance really is a science of sciences $[\tau \tilde{\omega} \nu$

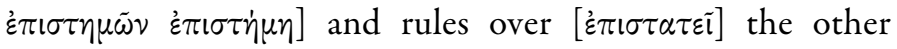
sciences, then I suppose it would rule $[\ddot{p} p \chi 0 v \sigma \alpha]$ over this
\end{abstract}

\footnotetext{
${ }^{44}$ Kahn 1996, 325 (emphasis mine): "As we have seen at the end of Chapter 7 [sc. on the connection between Charm. and Euthyd.], Socrates' second protreptic [sc. in Euthyd.] ends with a regress that can be resolved only when the content of the royal art is identified as the highest object of knowledge, the megiston mathêma of Republic VI." It is only the object of "the royal art" that is truly kinglike; cf. Rep.508a5 and Rep. 517b7-c5.

45 To which admission Socrates responds at Charm. 174b11-d2: “"You wretch," said I, "all this time you've been leading me right round in a circle and concealing from me that it was not living

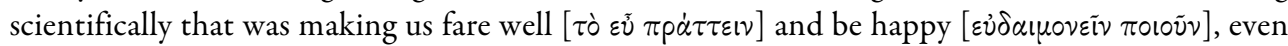
if we possessed all the sciences put together, but that we have to have this one science of good and

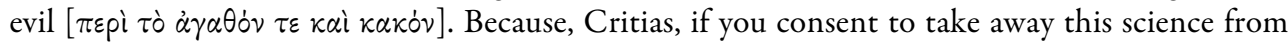
the other sciences, will medicine any the less produce health, or cobbling produce shoes, or the art of weaving produce clothes, or the pilot's art any the less prevent us from dying at sea or the general's art in war?" "They will do it just the same," he said. "But my dear Critias, our chance of getting any of these things well and beneficially [ $\omega \phi \varepsilon \lambda i \mu \omega \varsigma]$ done will have vanished if this is lacking." "You are right."”

${ }^{46}$ Charm. 174d2-7: ““'Then this science, at any rate, is not temperance, but that one of which the function is to benefit [ $\tau \dot{\partial} \dot{\omega} \phi \varepsilon \lambda \varepsilon \tilde{\imath} \nu]$ us. And it is not a science [ $\dot{\eta} \dot{\varepsilon} \pi \imath \tau \dot{\eta} \mu \eta]$ of science and absence of science but of good and evil [ $\dot{\alpha} \lambda \lambda \dot{\alpha} \dot{\alpha} \gamma \alpha \theta 0 \tilde{v} \tau \varepsilon$ k $\alpha \dot{\mathrm{l}} \kappa \alpha \kappa \circ \tilde{\nu}]$. So that, if this latter one is beneficial [ $\left.\dot{\omega} \phi \dot{\varepsilon} \lambda_{\mu}{ }_{0} \varsigma\right]$, temperance would be something else for us."”

${ }^{47}$ Cf. the merely physical sense of "idea" found at Charm.157d2, 158b1, and 175d7; cf. Euthyd. $271 \mathrm{~b} 4-5$.
}

PLATO, The electronic Journal of the International Plato Society, n 10, 2010. http://gramata.univ-paris1.fr/Plato/article95.html, (c) All rights of reproduction of any form reserved. 


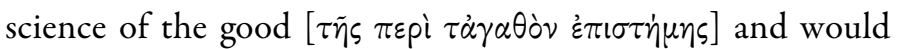
benefit $\left[\dot{\omega} \phi \varepsilon \lambda_{0}\right.$ iٓ] us." ${ }^{28}$

Socrates will naturally have nothing of this: after hurling Critias' earlier definition back in his teeth, ${ }^{49}$ he easily demonstrates that such knowledge is useless. $^{50}$ Socrates then takes the blame upon himself for being useless while nevertheless emphasizing that Critias too has been utterly defeated. ${ }^{51}$

But Charmides has nevertheless taken the reader an important step closer to Republic: a singular good ( $\tau \dot{\alpha} \gamma \alpha \theta \dot{\alpha} \nu$; cf. Sophist $251 \mathrm{c} 1$ ) has for the first time been identified as the highest object of knowledge rather than as the highest knowledge's intrinsic property or content, as was the case in Euthydemus. This process begins in Laches. ${ }^{52}$ In the earlier dialogue, the singular is absent: the analogous definition in the conversation with Nicias was "knowledge of goods

${ }^{48}$ Charm. 174d8-e2; cf. Eisenstadt 2008, 495: "However, Critias' remark at 174d8-e2 near the end of their discussion, shows that he still harbors his ambition to rule Athens in light of an epistemology which Socrates has attempted to refute [n. 12]." Eisenstadt 2008, 495 n. 12 concludes astutely (emphasis mine): "Presiding over others and dictating what is good and what is bad so as to benefit the few describes well the rule of the Thirty Tyrants in 404 B.C.E. among whom the historical Critias played a leading role." See also Notomi 2000, 247.

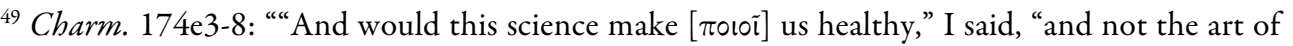
medicine? And would it perform [ $\pi \circ 10 i]$ the tasks of the other arts rather than each of them performing its own task [हैpyov]? Didn't we protest solemnly just a moment ago that it is a science

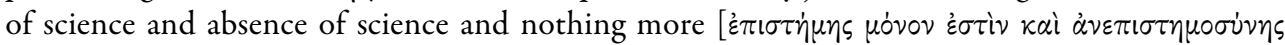

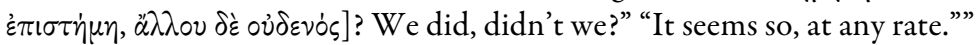

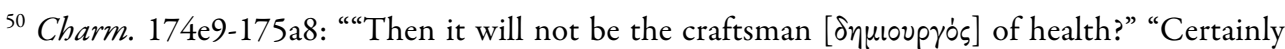
not." Because health belonged to another art, didn't it?" "Yes, to another." "Then it will be of no

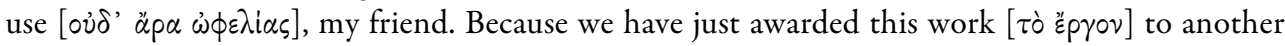

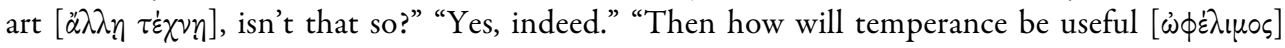

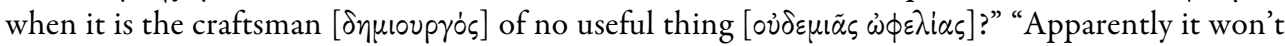
be of any use at all, Socrates."”

${ }^{51}$ Charm. 175a9-b4: “"You see then, Critias, that my earlier fears were reasonable and that I was right to blame myself for discerning nothing useful in temperance? Because I don't suppose that the thing we have agreed to be the finest of all $\left[\kappa \dot{\alpha} \lambda \lambda \lambda_{1 \sigma \tau} \sigma \nu \pi \dot{\alpha} \nu \tau \omega \nu\right]$ would have turned out to be

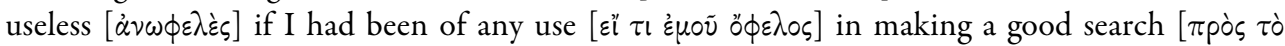
$\kappa \alpha \lambda \tilde{\omega} \varsigma \zeta \eta \tau \varepsilon \tilde{\imath} \nu]$. But now we have got the worst of it in every way [ $\pi \alpha \nu \tau \alpha \chi \tilde{\eta} \gamma \dot{\alpha} \rho \dot{\eta} \tau \tau \dot{\omega} \mu \varepsilon \theta \alpha]$ and are

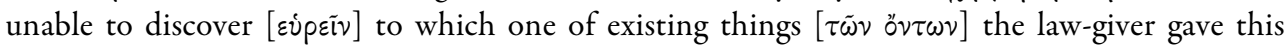
name, temperance."”

52 Kahn 1996, 150-4 ("2. The Laches as an Introductory Dialogue") especially 151: "One indication of the introductory function of the Laches is the unparalleled length of the dramatic prologue, which occupies the first half of the short work [note 3]." $151 \mathrm{n}$. 3: "Its closest rival is the triple prologue of Protagoras, which occupies ten [Stephanus] pages [Lach. "covers eleven"] in a dialogue more than twice the length of the Laches." An important part of this prologue will be considered in Section 5.

PLATO, The electronic Journal of the International Plato Society, n 10, 2010. http://gramata.univ-paris1.fr/Plato/article95.html, (c) All rights of reproduction of any form reserved. 
and evils." 53 Like "the science of the good" in Charmides, the knowledge of goods and evils in general overthrows Nicias' earlier future-oriented definition; ${ }^{54}$ as a result of adding past and present goods, he can easily be shown to have defined virtue as a whole rather than courage specifically. ${ }^{55}$ Whereas Critias shows himself willing to subordinate the knowledge of the good to his version of temperance rather than permit such knowledge to overthrow it, Socrates begins the process that will overthrow Nicias' definition of courage by slyly suggesting that Nicias will be willing — as he was during the retreat from Syracuse (Thucydides 7.50)_ to subordinate the knowledge he must surely have possessed qua general to the only science that truly makes future goods and evils its sole legitimate object. ${ }^{56}$ It is important to recognize that once we agree that neither dialogue can be understood without the reader's "mantic" 57 awareness of what fates await Nicias and Critias, the limits of "fictive chronology" become apparent even on

${ }^{53}$ Lach. 199a6-c2: "Socrates: Well then, do you agree with us, Nicias, that the same knowledge has understanding of the same things, whether future, present, or past? Nicias: Yes, that is how it seems to me, Socrates. Socrates: Now, my good friend, you say that courage is the knowledge of the fearful and the hopeful, isn't that so? Nicias: Yes, it is. Socrates: And it was agreed that fearful and hopeful were future goods $[\tau \dot{\alpha} \mu \dot{\varepsilon} \nu \mu \dot{\varepsilon} \lambda \lambda$ ov $\tau \alpha \dot{\alpha} \gamma \alpha \theta \dot{\alpha}]$ and future evils. Nicias: Yes, it was. Socrates: And that the same knowledge is of the same things-future ones and all other kinds. Nicias: Yes, that is the case. Socrates: Then courage is not knowledge of the fearful and the hopeful only,

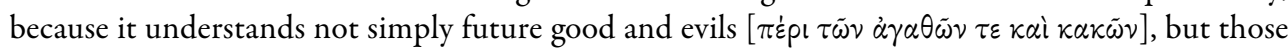
of the present and the past and all times, just as is the case with every other sort of knowledge. Nicias: So it seems, at any rate."

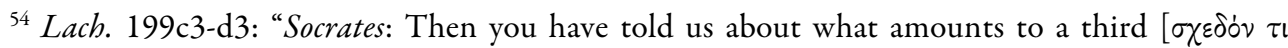

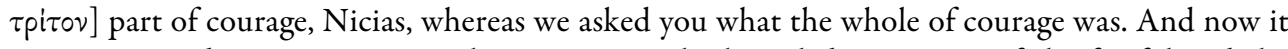
appears, according to your view, that courage is the knowledge not just of the fearful and the hopeful, but in your opinion, it would be the knowledge of practically [ $\sigma \chi \varepsilon \delta \dot{\delta} \nu \tau l]$ all goods and

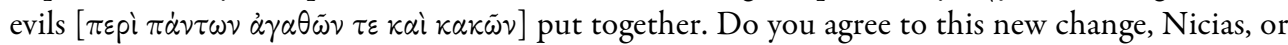
what do you say? Nicias: That seems right to me, Socrates."

${ }^{55}$ Lach. 199d4-e5: "Socrates: Then does a man with this kind of knowledge seem to depart from virtue in any respect if he really knows, in the case of all goods [ $\tau \dot{\alpha} \tau \varepsilon \dot{\alpha} \gamma \alpha \theta \dot{\alpha} \pi \dot{\alpha} \nu \tau \alpha]$ whatsoever, what they are and will be and have been, and similarly in the case of evils? And do you regard that man as lacking in temperance or justice or holiness to whom alone belongs the ability to deal circumspectly with both gods and men with respect to both the fearful and its opposite, and to provide himself with good things $[\tau \dot{\alpha} \gamma \alpha \theta \dot{\alpha}]$ through the knowledge of how to associate with them correctly? Nicias: I think you have a point, Socrates. Socrates: Then the thing you are now talking

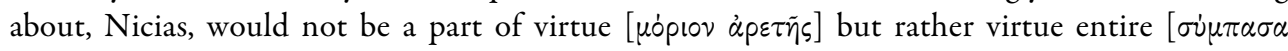

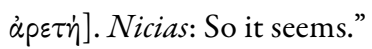

${ }^{56}$ Lach. 198e2-199a5: "Socrates: And I suppose that both of you could bear witness that, in the case of the affairs of war, the art of generalship is that which best foresees the future and the other times-nor does this art consider it necessary to be ruled by the art of the seer [ $\tau \tilde{\eta} \mu \alpha \nu \tau i k \tilde{\eta}]$, but to rule $[\ddot{\alpha} p \chi \varepsilon \iota \nu] i t$, as better acquainted with both present and future in the affairs of war. In fact, the law decrees, not that the seer should command the general, but that the general should command

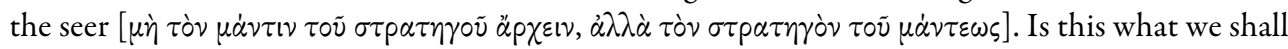
say, Laches? Laches: Yes, it is."

${ }^{57}$ Cf. Emlyn-Jones 1996, 115: “obviously a historical anachronism.”

PLATO, The electronic Journal of the International Plato Society, n 10, 2010. http://gramata.univ-paris1.fr/Plato/article95.html, (c) All rights of reproduction of any form reserved. 
chronological grounds: it is not only that the end of Critias followed that of Nicias but that Nicias' failure in Sicily made Critias' subsequent success at Athens possible. In short, despite merely chronological appearances, Charmides actually belongs to a far more advanced stage of Athenian degeneration than Laches (Schmid 1992, 179-80), a stage where the "easier"58 reduction of virtue to proficiency makes the moral worth of virtue an embattled concept, as it will soon enough prove to be in Gorgias. ${ }^{59}$

The underlying reason that the dilemma Critias faces brings us closer to Republic VI than the infinite regress of Euthydemus is that the subject under discussion in Charmides is a virtue, not a master form of knowledge. Of course virtue may be knowledge (hence the intellectualist position entrusted by Plato to Nicias and Critias; cf. Devereux 1977) but it certainly is good; unlike all other forms of knowledge, "the royal art" of Euthydemus must produce results that are good without qualification. Careful consideration of the introductory passage in

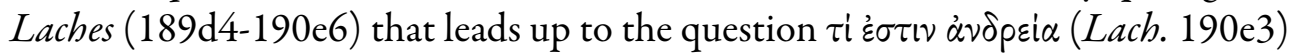
will reveal it to be the point of transfer between the elusive knowledge that makes men good in Euthydemus and the collapse of "the knowledge of knowledge" as a definition of temperance in Charmides.

\section{Section 5. What Begins in Laches}

Socrates: Let us do what Lysimachus and Melesias suggest, Nicias and Laches. Perhaps it won't be a bad idea [ov̉ kakw s] to ask ourselves the sort of question we proposed just now: what teachers have we had in this sort of instruction, and

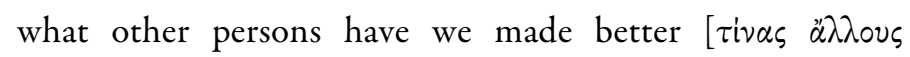
$\beta \varepsilon \lambda \tau i$ iov $\pi \varepsilon \pi \circ(\eta \dot{k} \alpha \mu \varepsilon v]$ ?

(Lach. 189d4-e1)

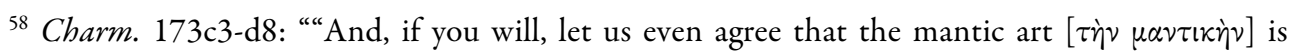
knowledge of what is to be and that temperance, directing her, keeps away deceivers and sets up true seers [ $\tau 0 \dot{\nu} \varsigma \delta \dot{\varepsilon} \dot{\omega} \varsigma \dot{\alpha} \lambda \eta \theta \tilde{\omega} \varsigma \mu \dot{\alpha} \nu \tau \varepsilon l \varsigma]$ as prophets of the future. I grant that the human race, if thus

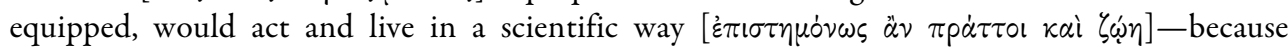
temperance, watching over it, would not allow the absence of knowledge to creep in and become

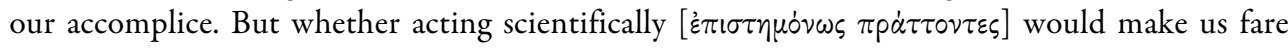

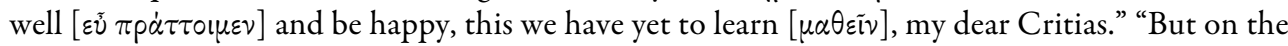

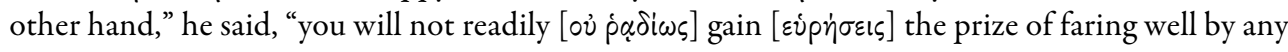

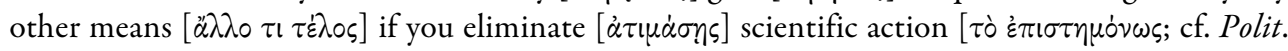
$293 \mathrm{c} 5$-d 3 for the removal of all restrictions on those who are $\dot{\varepsilon} \pi\llcorner\sigma \tau \mu \dot{\delta} v \omega \varsigma \pi \rho \dot{\alpha} \tau \tau 0 \nu \tau \varepsilon \zeta]$." "Instruct

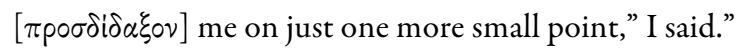

59 Recent scholarship suggests that Gorg. will one day be recognized as a "virtue dialogue" concerned with justice: see Stauffer 2006 and Gorg. 527b2-c4.
}

PLATO, The electronic Journal of the International Plato Society, n 10, 2010. http://gramata.univ-paris1.fr/Plato/article95.html, (c) All rights of reproduction of any form reserved. 
As already shown in Section 2, this passage marks a break with Alcibiades Major: in accordance with the practical bent of Laches, Socrates replaces the selfdiscovery of theoretical knowledge with a proven capacity to make others better. And this capacity shows that we still have one foot in the world of Euthydemus where-quite apart from the claim that Socrates qua teacher actually makes Ctesippus both good and happy there-the knowledge sought is "the one by

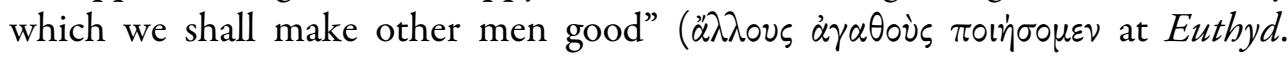

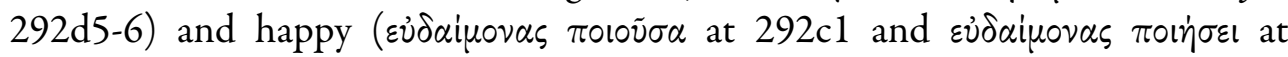
292e5). Thanks to the emergence of the $\tau \dot{i} \dot{\varepsilon} \sigma \tau \nu \dot{\alpha} \nu \delta \rho \varepsilon i \alpha$ question, this world is going to be left behind-or rather, it will appear to have been left behind-in Laches:

However, I think there is another sort of inquiry that will

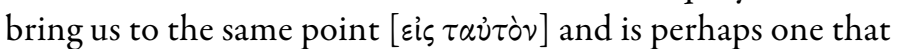
begins somewhat more nearly [ $\sigma \chi \varepsilon \delta \dot{\delta} \nu \delta \dot{\varepsilon} \tau \iota$ kai $\mu \tilde{\alpha} \lambda \lambda \circ \nu]$ from the beginning [ $\dot{\xi} \xi \dot{\alpha} p x \tilde{\eta} s]$.

(Lach. 189e1-3)

With this remarkably tentative description, Socrates next introduces this new sort of inquiry-an inquiry that will lead eventually to the question: "what is courage?"-in a remarkably opaque manner:

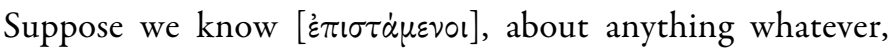

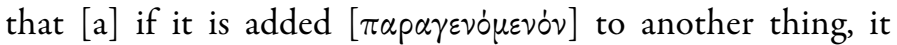

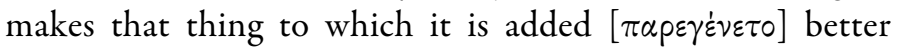

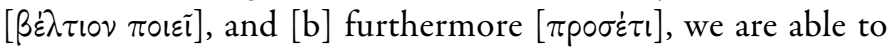

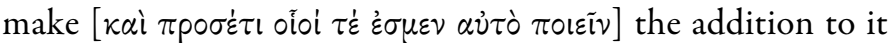

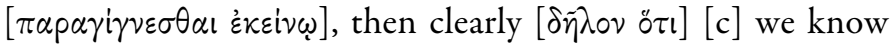
the very thing about which we've become counselors [aj $\tau^{\prime} \gamma \varepsilon$

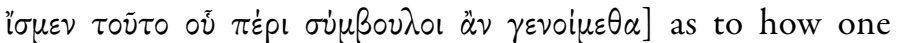

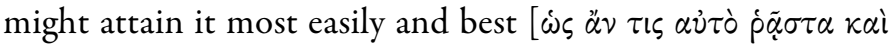

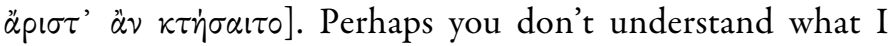
mean... ${ }^{60}$

This self-consciously confusing passage plays an important role on the path that leads to Republic VI not only in an ontological but also in a methodological sense (cf. Kohák 1960 and Hoerber 1968, 103-4): it anticipates the passage, likewise misunderstood by Socrates' interlocutor (Glaucon), that first defines the penultimate section of the Divided Line without any reference to either geometry or arithmetic (Rep. 510b4-10), the latter introduced only later to explain the explicitly difficult general description that precedes it (Rep. 510c1-511a2). This procedure is clearly intentional on Plato's part: in both cases, the careful reader

${ }^{60}$ Lach. 189e3-7. Sprague's translation modified: I have added "to which it is added" (㐫 $\pi \alpha \rho \varepsilon \gamma^{\dot{\varepsilon} \nu \varepsilon \tau 0)}$ and added "to it" ( $\pi \alpha \rho \alpha \gamma i \gamma \nu \varepsilon \sigma \theta \alpha \iota$ ह่ $\left.\kappa \varepsilon i \nu \omega\right)$ and have substituted "we've become

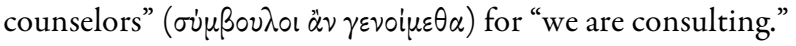

PLATO, The electronic Journal of the International Plato Society, n 10, 2010. http://gramata.univ-paris1.fr/Plato/article95.html, (c) All rights of reproduction of any form reserved. 
must consider the general and more confusing definition on its own merits. In Laches, the thing to be added (the verb $\pi \alpha \rho \alpha \gamma i \gamma \nu \varepsilon \sigma \theta \alpha \mathrm{l}$ is the Leitmotiv of the entire passage under consideration) ${ }^{61}$ will become virtue (or rather a part of it) and therefore, in accordance with [a], something that necessarily makes us better. Although this sort of inquiry will no longer require us to identify our teacher, [b] presupposes what I have called "the world of Euthydemus" and although this premise will soon silently disappear from view, its presence draws attention to the effectiveness of Socrates qua teacher: it is on the basis of the action (if not the argument) of Euthydemus that condition [b] is or rather has already been met and that the conclusion of Laches is consistent with the failure to define courage in words. ${ }^{62}$ The germ of the immediate future-i.e. a series of "virtue dialogues" where the evidently virtuous Socrates will fail to elicit definitions of the virtuesis found in $[\mathrm{c}]$, a germ that will cause the unwary to forget its explicit and continuing dependence on [b]. But [a] should not be slighted: the external Good will eventually emerge from its logical priority to this particular $\beta \dot{\varepsilon} \lambda \tau \imath$ v.

Perhaps you don't understand [oن $\mu \alpha \nu \theta \dot{\alpha} \nu \varepsilon \tau \dot{\varepsilon}$ ] what I mean, but will do so more easily [ $\dot{\rho} \tilde{\alpha} \circ \nu \mu \alpha \theta \dot{\eta} \sigma \varepsilon \sigma \theta \varepsilon]$ in this way: suppose we know that $[\mathrm{A}]$ sight, when added [ $\pi \alpha \rho \alpha \gamma \varepsilon v o \mu \varepsilon \dot{\nu} \eta]$ to the eyes, makes better those eyes to which it is added

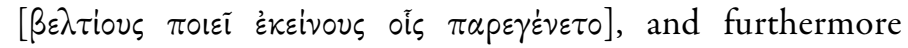
$[\pi p \circ \sigma \dot{\varepsilon} \tau l],[\mathrm{B}]$ we are able to add $[\pi \alpha p \alpha \gamma i \gamma \nu \varepsilon \sigma \theta \alpha \mathrm{l}]$ it to the eyes, then clearly $[\delta \tilde{\eta} \lambda \circ \nu \circ \tau \iota][C-1]$ we know what this very

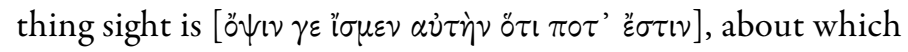
we should be consulting as to [C-2] how one might obtain it

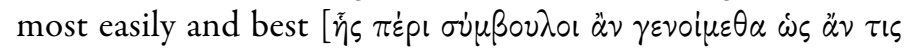
$\alpha \dot{v} \tau \dot{\eta} \nu \dot{\rho} \tilde{\alpha} \sigma \tau \alpha \kappa \alpha i \grave{\alpha} \rho \mid \sigma \tau \alpha \kappa \tau \dot{\eta} \sigma \alpha \iota \tau o] .{ }^{63}$

The example of vision and sight-even without any reference to the objective Sun-offers another parallel to (or rather a proleptic anticipation of) Republic VI. But the crucial matter for now is that the germ of the $\tau i \dot{\varepsilon} \sigma \tau \iota$ question, applied to

${ }^{61}$ For a valuable discussion of the verb, see Schmid 1992, 96 and Theages 130d1-2; note that Socrates is questioning Aristides son of Lysimachus (Theages 130a4-5). There is thus something to be said for the view that Socrates is the thing that "when added" ( $\pi \alpha p \alpha \gamma i \gamma \nu \varepsilon \sigma \theta \alpha \mathrm{l})$ makes the souls of the youth better. Cf. Schmid 1992, 196 n. 5 and 209 n. 6. Cf. O’Brien 1963, 147.

${ }^{62}$ Kohák 1960, 123 (on the tripartite structure of Lach.): "There will be, first of all, the introduction in which Lysimachus and Melesias discuss with Nicias and Laches the education of young men in general and that of their own sons in particular. Then there will be the body of the dialogue which inquires unsuccessfully into the nature of courage, and finally a conclusion in which Lysimachus requests further instruction from Socrates-in spite of the fact that Socrates is supposed to have failed to solve the problem posed in the body of the dialogue. Not only is there a definite conflict between the body and the conclusion, we also have a twelve-page preface introducing a seven-page dialogue."

${ }^{63}$ Lach. 189e7-190a5. See Schmid 1992, 96 for the repeated use of $\mu \alpha \nu \theta \dot{\alpha} \nu \varepsilon เ v$.

PLATO, The electronic Journal of the International Plato Society, n 10, 2010. http://gramata.univ-paris1.fr/Plato/article95.html, (c) All rights of reproduction of any form reserved. 
the virtues here, has been tacitly smuggled into this second version. Despite numerous verbatim repetitions, $[\mathrm{c}]$ has undergone an easily overlooked but obvious transition: in the general statement, in accordance with the practical concerns of Melesias and Lysimachus, the very thing we know ( $\alpha \dot{v} \tau \dot{\delta} \gamma \varepsilon$ i $\sigma \mu \varepsilon \nu$ $\tau \circ \tilde{v} \tau$ ) is at best merely a means of making their sons better in the best and easiest way. ${ }^{64}$ By adding the fateful words ö $\tau \iota \pi \circ \tau^{\prime}$ है $\sigma \tau \iota \nu,[\mathrm{C}-1]$ now gains heuristic independence for the $\tau i \dot{\varepsilon} \sigma \tau \iota$ question as distinct from the practical goal, then restated verbatim in [C-2]. Socrates immediately emphasizes the importance of this change just in case we missed it:

Because if we knew neither this very thing [ $\alpha \dot{\tau} \tau \grave{c} \tau o \tilde{\tau} \tau 0]$-i.e. [ö $\tau l]$ what sight is $\left[\pi \circ \tau^{\prime} \ddot{\varepsilon} \sigma \tau \iota \nu \partial^{\prime} \psi(\varsigma)\right.$-nor hearing, we would hardly be worthy counselors and doctors about either the eyes or the ears as to the manner in which either sight or hearing might best be obtained. Laches: You are right, Socrates. ${ }^{65}$

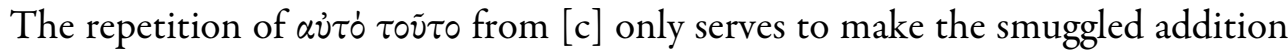
of ö $\tau \iota \pi \circ \tau^{\prime}$ 'ँ $\sigma \tau \iota \nu$ from [C-1] all the more conspicuous; it is from this addition that the series of virtue dialogues-first Laches and then Charmides-now takes its start:

Socrates: Well then, Laches, aren't these two now asking our

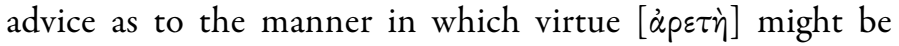
added [ $\pi \alpha \rho \alpha \gamma \varepsilon v o \mu \varepsilon v \eta]$ to the souls of their sons to make them

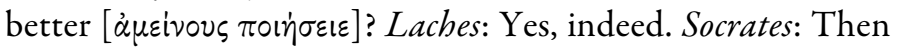

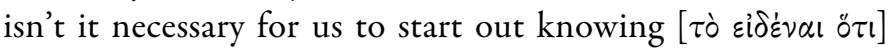
what virtue is $\left[\pi \circ \tau^{\prime} \ddot{\varepsilon} \sigma \tau \imath \nu \dot{\alpha} \rho \varepsilon \tau \dot{\eta}\right]$ ?

(Lach. 190b3-b8)

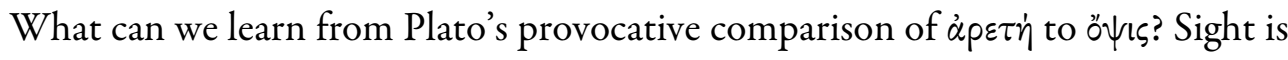
a natural capacity of the eye; an eye without sight is defective and requires the immediate attention of a doctor. It is therefore natural to speak of restoring sight to the eyes; a doctor who accomplished this result would certainly be making the eyes better but would be doing so only by restoring the characteristic excellence of an eye (Rep. 518c4-d2). The analogy does not emphasize the knowledge of the doctor (cf. Rep. 518d3-7) as much as it does the natural function of the eye; the

64 "At best" because there is a natural temptation to read the eye/sight passage back into the general one, as does Emlyn-Jones 1992, 90-1.

${ }^{65}$ Lach. 190a6-b2. Sprague translates: "Because if we didn't know what sight in itself was..."

PLATO, The electronic Journal of the International Plato Society, n 10, 2010. http://gramata.univ-paris1.fr/Plato/article95.html, (c) All rights of reproduction of any form reserved. 
doctor's art cooperates with and thereby restores that function. ${ }^{66}$ Virtue is therefore the natural excellence of the soul best understood as a natural capacity of the soul, a capacity to do something. Since sight is best understood as the action characteristic of the eye; Socrates is therefore suggesting that virtue is also best understood as an action. If virtue is like sight, it too must be directed at certain external objects: the capacity to see connects the eyes to the objects of sight. Only in Republic VI (Rep. 507d8-508c2) will Plato or Socrates remind us that this connection presupposes light and indeed the source of light. A natural question is: what are the external objects upon which virtue operates and for an answer, we will need to wait. But in the context of McCabe's important distinction between Republic VI and Euthydemus, the important point is that the turn from an internal good (like knowledge) to an external one-whether the good in question proves to be more similar to the objects of sight or the source of light that makes vision possible-occurs in Laches.

If only because they presumably love Socrates, Plato scholars should really be more considerate of Laches the man: Plato presents him as praising our hero both well and truly (Lach. 181a7-b4 and 189b1-6). But Laches also sells himself short in the following exchange:

Socrates: Because if we are not absolutely certain what it is

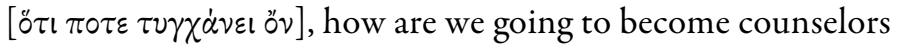

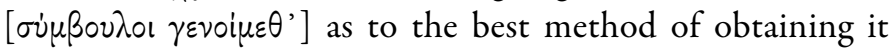

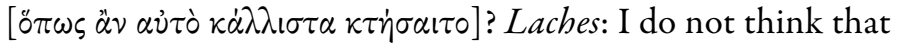
there is any way in which we can do this, Socrates. ${ }^{67}$

In fact, Laches offers Lysimachus and Melesias consummate counsel even without appearing to possess such knowledge: they should consult Socrates as to the education of Thucydides and Aristides. If Laches is not absolutely certain as to what courage happens to be, he certainly recognizes virtue when he sees it or, to speak more precisely, when he actually saw it with his own eyes in action, embodied in the son of Sophroniscus at Delium (Lach. 189b5). A sense for history requires us to remember that a fighting retreat requires more courage than a spirited assault; it seems reasonable that Laches not only saw Socrates conducting himself in a calm and steadfast manner under pressure from a

\footnotetext{
${ }^{66} \mathrm{Schmid}$ 1992, 97: "In addition to this main point [sc. the need for teleological knowledge implied by the analogy, i.e. "we need to understand what man or human life is for"], the analogy raises a number of other suggestions, though it is not obvious what, if anything, we are to do with them. One is that virtue is somehow natural, the soul doctor's task not being one of putting something alien into souls that are innately blind but rather one of removing impediments to what is already there."

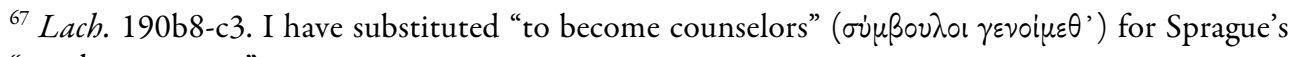
"to advise anyone."
} 
confident and irresistible foe but also saw him steadying others who were despondent and frightened. Although it would be difficult to say whether the objects of Socrates' virtuous actions at Delium were his friends, his enemies, his commanders, his subordinates, or himself, his courage was necessarily embodied in actions and indeed is meaningless without them. We must therefore wonder: can virtue really be knowledge simplement?

Socrates: We say then, Laches, that we know what it is [ $\varepsilon^{i} \delta \delta^{\prime} v \alpha \mathrm{l}$

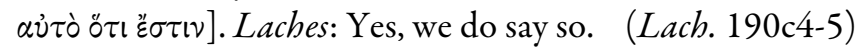

The armchair philosopher (cf. Witte 1970, 139 and Tuckey 1951, v), especially one who is aware of the crucial importance of dramatic context while interpreting Platonic dialogues, would do well to remember that the "we" that joins Socrates and Laches is the first-person plural of comrades in arms who have stood shoulder to shoulder in battle: ${ }^{68}$ these men saw each other in action and know that each of them knows what he saw of the other (cf. Symp. 220e7-221c1), just as they both saw many others who behaved disgracefully.

Socrates: And what we know, we must, I suppose, be able to

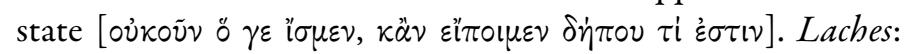

Of course.

(Lach. 190c6-7)

Any reader who has been tested in battle knows that this is simply not true: soldiers are suspicious of talk where courage is concerned. I suggest that this is why Plato named the dialogue after Laches. Socrates already knows that Laches will not be able to state what courage is but that he will bravely try to do so when asked to do so by a respected comrade. It is often overlooked that Socrates is responsible for replacing Laches with Nicias as an interlocutor (Lach. 194b8-c1). By contrasting him with Laches, Plato's artistry ensures that we will recognize that Nicias has confidence in words, not deeds, in knowledge, not action, in himself, but not in Socrates. ${ }^{69}$

Socrates: Let us not, $\mathrm{O}$ best of men, begin straightway with an investigation of the whole of virtue- that would be too great a task-but let us first see if we have sufficient knowledge of a part. Then it is likely that the investigation will be easier

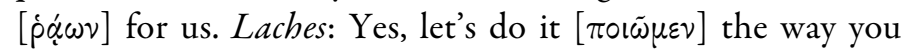
want, Socrates.

(Lach. 190c8-d2)

\footnotetext{
${ }^{68}$ Emlyn-Jones 1999, 134 does well to remind us of the disjunction between "fighting in armor" and the phalanx.

${ }^{69}$ For an advance on de Laguna 1934, see Dobbs 1986, especially 828-9 n. 2 and 848.

PLATO, The electronic Journal of the International Plato Society, n 10, 2010. http://gramata.univ-paris1.fr/Plato/article95.html, (c) All rights of reproduction of any form reserved.
} 
The use of the word $\pi \circ 1 \tilde{\omega} \mu \varepsilon \nu$ proves that Laches, good soldier that he is, has not lost sight of the dialogue's principal objective: the education of young Aristides and Thucydides. Although the investigation of a part of virtue will not in fact prove easier $(\dot{\rho} \alpha \omega \omega)$, Meno will prove that the alternative approach is scarcely foolproof. In any case, Laches is correct: the noblest $(\kappa \dot{\alpha} \lambda \lambda เ \sigma \tau \alpha)$, the best, and the easiest way for the sons of Melesias and Lysimachus to acquire virtue is through the ministrations of Socrates, whether or not he or anyone else can articulate what courage is.

Socrates: Well, which one of the parts of virtue should we choose? Or isn't it obvious that we ought to take the one to which the technique $[\mu \dot{\alpha} \theta \eta \sigma \iota]$ of fighting in armor tends to

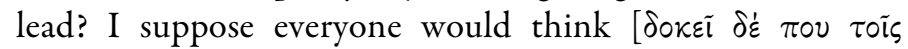
$\left.\pi \circ \lambda \lambda \circ i_{\varsigma}\right]$ it leads to courage, wouldn't they? Laches: I think they certainly would. Socrates: Then let us undertake first of all, Laches, to state what courage is [ $\left.\dot{\alpha} \nu \delta \rho \varepsilon i \alpha \tau i \pi \circ \tau^{\prime} \dot{\varepsilon} \sigma \tau i \nu\right]$.

(Lach. 190d3-8)

Socrates does not call courage a $\mu \dot{\alpha} \theta \eta \sigma \iota ;$ it is only "the many" who would imagine that training in e.g. the martial arts conduces to bravery on the battlefield. There were probably skilled athletes among those who panicked at Delium and ignorant rustics who fought like heroes. But the important point is that for the first time, the $\tau i \dot{\varepsilon} \sigma \tau i$ question is about to be applied to a virtue (the $\tau \dot{i} \pi \circ \tau^{\prime} \dot{\varepsilon} \sigma \tau i \nu$ is transitional); the complex introduction that precedes it in Laches is another proof of this pedagogical priority. Suggesting as it does that courage is something that is talked about, not done, this question will receive no answer here. But the question brings us closer to the Good than "the royal art" of Euthydemus, despite the latter's apparent proximity to Republic.

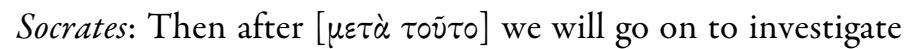
in what way it could be added [ $\pi \alpha \rho \alpha \gamma^{\prime} v o$ i $\tau$ ] to the young, to the extent that the addition $[\pi \alpha \rho \alpha \gamma \varepsilon v \varepsilon \dot{\varepsilon} \sigma \theta \alpha \mathrm{l}]$ can be made through occupations and studies. But try to state what I ask, namely, what courage is $[\tau i \dot{\varepsilon} \sigma \tau \imath \nu \dot{\alpha} \nu \delta \rho \varepsilon i \alpha]$.

(Lach. 190d8-e3)

Here it is at last: the famous question has finally emerged from the mysterious description of "another sort of inquiry," a pedigree Plato emphasizes by sounding the Leitmotiv once again with $\pi \alpha \rho \alpha \gamma \varepsilon v \dot{\varepsilon} \sigma \theta \alpha$. There will, of course, be no $\mu \varepsilon \tau \dot{\alpha}$

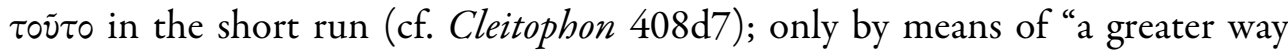
round" (Rep. 504b2) will Socrates bring Plato's brother (and Plato will bring the reader) towards the distant goal of Republic VII. But even though Critias will be the first to mention $\tau \dot{\alpha} \gamma \alpha \theta \dot{o} v$, we are already far closer to it than one might think, thanks to Laches:

PLATO, The electronic Journal of the International Plato Society, n 10, 2010. http://gramata.univ-paris1.fr/Plato/article95.html, (c) All rights of reproduction of any form reserved. 
Laches: Good heavens, Socrates, there is no difficulty about that: if a man is willing [ $[\dot{\varepsilon} \theta \dot{\varepsilon} \lambda \circ 1]$ to remain at his post [ $\dot{\varepsilon} \nu \tau \tilde{\eta}$ $\tau \dot{\alpha} \xi \varepsilon l \mu \dot{\varepsilon} \nu \omega \nu]$ and to defend himself against the enemy without

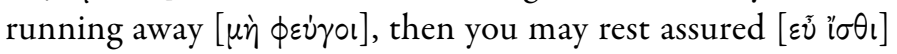
that he is a man of courage. Socrates: Well spoken, Laches. ${ }^{70}$

It would be a terrible mistake to image that Socrates' response here is ironic: Laches has spoken well and the fate of Socrates proves it. The manifest joke of both Laches and Charmides-another important connection between the twois that the actions of Socrates prove that he manifestly possesses the virtues whose verbal definitions remain elusive (Gonzalez 1995, 163-71); he will soon enough similarly prove himself to be just (Gorg. 521d6-e2), wise (Theages 130e5-10), and pious (Men. 99e3-100b7). ${ }^{71}$ But there was a reason why Plato began the series of "virtue dialogues" with courage, as the famous passage where Socrates explains why he moved past even the most promising of the physicists in the final Phaedo shows:

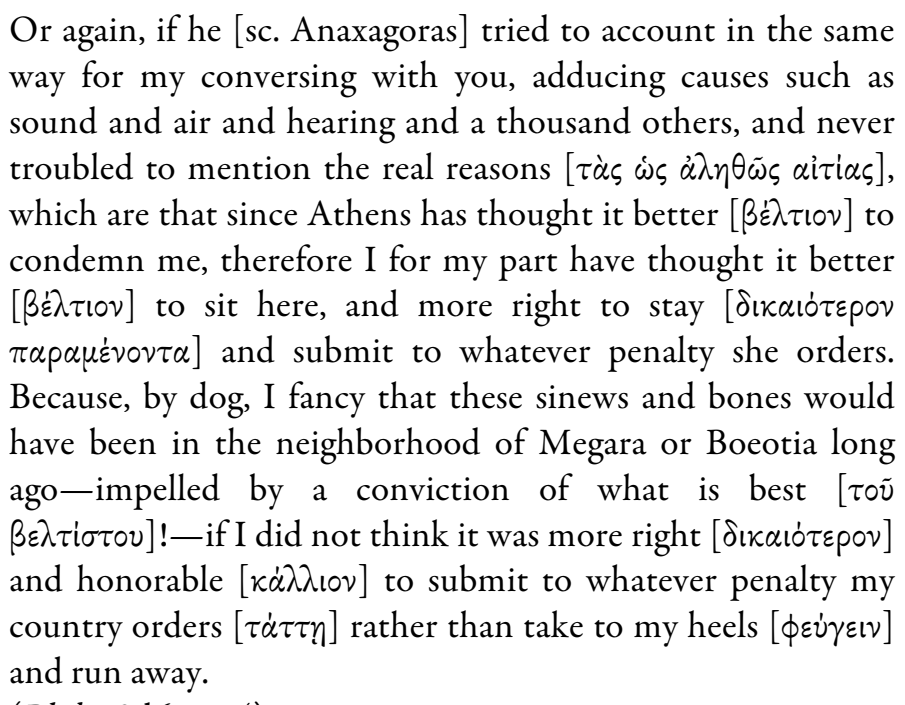
(Phd. 98d6-99a4)

Nor is this final vindication of Laches' first definition an isolated instance as Apology 28d-29b9 proves: a passage that is not only studded with variants of $\dot{\varepsilon} \nu \tau \tilde{\eta}$ $\tau \dot{\alpha} \xi \varepsilon l$ (Apol.28d7, 28d8, and 29a1), $\mu \dot{\varepsilon} \nu \omega \nu$ (Apol.28d8; cf. Dieterle 1966, 59 n. 3),

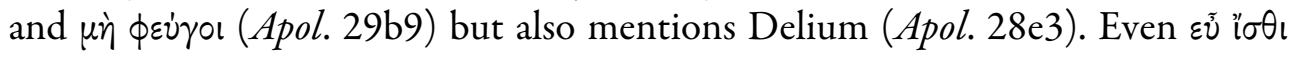

\footnotetext{
${ }^{70}$ Lach. 190e4-7; see Schmid 1992, 100 on $\dot{\theta} \theta \dot{\varepsilon} \lambda$ ol.

${ }^{71}$ See O'Brien 1963, 134-5 n. 5 for the two ways of reading Lach. summarized at Hoerber 1968, 105: "either as an attack on the thesis that virtue is knowledge, or as an argument for the unity of virtue." Considering a series of "virtue dialogues" beginning with Lach. and leading up to Rep. offers a middle course between these extremes: each virtue is distinct but all are equally dependent on the Good. For knowledge of ignorance of the Good, see Tuckey 1951, 82.
} 
puts in another appearance there and those who insist on a lethal cocktail composed of Socratic ignorance and "virtue is knowledge" - a world Plato will connect with Critias in Charmides ${ }^{72}$ - would do well to remember Apology 29b6$7,{ }^{73}$ a passage that reminds us that the process through which the reader finally comes to recognize that "the better" is not something internal like knowledge, began in Laches.

William H.F. Altman

${ }^{72}$ For a "Critian" reading of Lach., see Rabieh 2006, 160: “A philosopher's courage ultimately depends, then, on the knowledge that the wise and happy human being always pursues what is best for himself in the circumstances...In this way, a philosopher, in a certain sense, always pursues what is good."

73 "But to do wrong and disobey one's superior [ $\tau \tilde{\omega} \beta \varepsilon \lambda \tau i$ iovı $]$-yes, God and man — that this is evil and shameful, I know." Translation mine.

PLATO, The electronic Journal of the International Plato Society, n 10, 2010.

http://gramata.univ-paris1.fr/Plato/article95.html,

(c) All rights of reproduction of any form reserved. 


\section{Works Cited}

Altman, William H.F. 2007. "Leo Strauss and the Euthydemus." Classical Journal 102, 355-379.

. 2010. “The Reading Order of Plato's Dialogues.” Phoenix 64, 18-51.

BURNET, John. 1900-07. Platonis Opera. Oxford: Clarendon Press.

Crombie, I.M. 1962. An Examination of Plato's Doctrines I. London: Routledge $\&$ Kegan Paul.

DieTERLE, Reinhold. 1966. Platons Laches und Charmides; Untersuchungen zur elenktisch-aporetischen Struktur der platonischen Frühdialoge. (Dissertation; Freiburg).

DenYer, Nicholas (ed.). 2001. Plato, Alcibiades. Cambridge: Cambridge University Press. .2008. Plato, Protagoras. Cambridge: Cambridge University Press.

Devereux, Daniel T. 1977. "Courage and Wisdom in Plato's Laches." Journal of the History of Philosophy 15, 129-41.

.1992. "The Unity of Virtue in Plato's Protagoras and Laches." Philosophical Review 101, 765-789.

DoBBS, Darrell. 1986. "For Lack of Wisdom: Courage and Inquiry on Plato's Laches." Journal of Politics 48, 825-849.

EISENSTADT, Michael. 2008. "Critias' Definitions of $\sigma \omega \phi p o \sigma \dot{v} \eta$ in Plato's Charmides." Hermes 136, 492-495.

EMLYN-JONES, Chris (ed.). 1996. Plato, Laches. London: Bristol Classical Press. . 1999. "Dramatic Structure and Cultural Context in Plato's Laches." Classical Quarterly 49 (n.s.), 123-138.

ERBSE, Hartmut. 1968. "Über Platons Methode in den Sogenannten Jugenddialogen." Hermes 96, 21-40.

Friedländer, Paul. 1964. Plato II. Translated by Hans Meyerhoff. New York: Pantheon.

GOMPERZ, Theodor.1912. Griechische Denker II (3 ${ }^{\text {rd }}$ edition). Leipzig: Veit.

GonZalez, Francisco J. 1995. "Self-Knowledge, Practical Knowledge, and Insight: Plato's Dialectic and Dialogue Form.” In Francisco J. Gonzalez (ed.), The Third Way; New Directions in Platonic Studies. Lanham: Rowman \& Littlefield.

. 1998. Dialectic and Dialogue; Plato's Practice of Philosophical Inquiry. Evanston: Northwestern University Press.

Gould, Carol S. 1987. "Socratic Intellectualism and the Problem of Courage: An Interpretation of Plato's Laches. History of Philosophy Quarterly 4, 265-279.

GRISwOLD, Charles L. Jr. 1999. "E Pluribus Unum? On the Platonic 'Corpus.” Ancient Philosophy 19, 361-397.

GuTHRIE, W.K.C. 1975. A History of Greek Philosophy IV. Cambridge: Cambridge University Press. 
Hyland, Drew. 1981. The Virtue of Philosophy; An Interpretation of Plato's Charmides. Athens: Ohio University Press.

KaHN, Charles H. 1981. "Did Plato Write Socratic Dialogues." Classical Quarterly 31 (n.s.), 305-320.

- 1988. "Plato's Charmides and the Proleptic Reading of Socratic Dialogues." Journal of Philosophy 85, 541-549.

. 1993. "Proleptic Composition in the Republic, or Why Book 1 Was Never a Separate Dialogue." Classical Quarterly 43 (n.s.), 131-42. . 1996. Plato and the Socratic Dialogue; The Philosophical Use of a Literary Form. Cambridge: Cambridge University Press.

KоHÁK, Erazim V. 1960. "The Road to Wisdom: Lessons on Education from Plato's Laches." Classical Journal 56, 123-132.

De Laguna, Theodore. 1934. "The Problem of the Laches." Mind 43 (n.s.), 170180.

LAMPERT, Laurence. 2010. How Philosophy Became Socratic: A Study of Plato's Protagoras, Charmides, and Republic. Chicago: University of Chicago Press.

MCCABE, Mary Margaret. 2002. "Developing the Good itself by itself: Critical Strategies in Plato's Euthydemus." Journal of the International Plato Society 2 (http://www.nd.edu/ plato/plato2issue/mccabe.htm)

. 2007. "Looking Inside Charmides' Cloak: Seeing Others and Oneself in Plato's Charmides. In Dominic Scott (ed.), Maieusis: Essays on Ancient Philosophy in Honour of Myles Burnyeat, Oxford: Oxford University Press, 2007; 1-19.

Miller, Mitchell H. Jr. 1986. Plato's Parmenides: The Conversion of the Soul. University Park: Pennsylvania State University Press.

Mutschmann, Hermann. 1911. "Zu Platons Charmides." Hermes 46, 473-478.

NAILS, Debra. 2002. The People of Plato: A Prosopography of Plato and Other Socratics. Indianapolis: Bobbs-Merrill.

NAtorp, Paul. 1914. Platons Ideenlehre. Berlin: Reuther \& Reichard.

Notomi, Noburu. 2000. "Critias and the Origin of Plato's Political Philosophy."

In T.M. Robinson and Luc Brisson (eds.), Plato: Euthydemus, Lysis, Charmides. Selected Papers from the Fifth Symposium Platonicum, Sankt Augustin: Academia Verlag, 2000; 235-250.

O'Brien, Michael J. 1963. "The Unity of the Laches." Yale Classical Studies 18, 133-147.

PohlenZ, Max. 1913. Aus Platos Werdezeit; philologische Untersuchungen. Berlin: Weidmann.

PRESS, Gerald A. 1993. "Principles of Dramatic and Non-dogmatic Plato Interpretation" and "Introduction" to Press (as Ed.), Plato's Dialogues: New Studies and Interpretations. Lanham: Rowman \& Littlefield.

RabieH, Linda R. 2006. Plato and the Virtue of Courage. Baltimore: Johns Hopkins University Press. 
Rowe, Christopher. 2007. Plato and the Art of Philosophical Writing. Cambridge: Cambridge University Press.

SANTAS, Gerasimos. 1971. "Socrates at Work on Virtue and Knowledge in Plato's Laches." In Gregory Vlastos, ed., The Philosophy of Socrates. Garden City: Doubleday, Anchor Books, 1971; 177-208. - 1973. "Socrates at Work on Virtue and Knowledge in Plato's Charmides." In E.N. Lee, A.P.D. Mourelatos, Richard M. Rorty, eds., Exegesis and Argument: Studies in Greek Philosophy Presented to Gregory Vlastos. Assen: Van Gorcum, 1973; 105-132.

SCHMID, Walter T. 1992. On Manly Courage: A Study of Plato's Laches. Carbondale and Edwardsville: Southern Illinois University Press. . 1998. Plato's Charmides and the Socratic Ideal of Rationality. Albany: State University of New York Press.

Sprague, Rosamond Kent. 1973. Plato: Laches and Charmides; Translated with an Introduction and Notes. Indianapolis: Bobbs-Merrill.

StAuffer, Devin. 2006. The Unity of Plato's Gorgias: Rhetoric, Justice, and the Philosophic Life. Cambridge: Cambridge University Press.

STRAUSS, Leo. 1966. Socrates and Aristophanes. New York: Basic Books. . 1989. The Rebirth of Classical Political Rationalism; An Introduction to the Thought of Leo Strauss. Edited by Thomas L. Pangle. Chicago: University of Chicago Press.

TuCKey, T.G. 1951. Plato's Charmides. Cambridge: Cambridge University Press.

VAn Der Ben, N. 1985. The Charmides of Plato: Problems and Interpretation. Amsterdam: B.R. Grüner.

WiTTE, Bernd. 1970. Die Wissenschaft vom Guten und Bösen; Interpretationen zu Platons 'Charmides.'Berlin: Walter de Gruyter.

WolfsDorf, David. 2003. "Plato's Pursuit of Definitions." Phronesis 48, 271312.

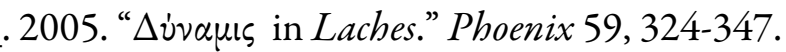

Zuckert, Catherine. 1996. Postmodern Platos: Nietzsche, Heidegger, Gadamer, Strauss, Derrida. Chicago: University of Chicago Press. . 2009. Plato's Philosophers; The Coherence of the Dialogues. Chicago: University of Chicago Press. 